\title{
Biostratigraphic, evolutionary, and paleoenvironmental significance of the southernmost lepidocyclinids of the Pacific coast of South America (East Pisco Basin, southern Peru)
}

\author{
Giovanni Coletti $^{\mathrm{a}, *}$, Giulia Bosio ${ }^{\mathrm{a}, \mathrm{b}}$, Alberto Collareta ${ }^{\mathrm{b}, \mathrm{c}}$, Elisa Malinverno ${ }^{\mathrm{a}}$, \\ Valentina Alice Bracchi ${ }^{\mathrm{a}}$, Claudio Di Celma ${ }^{\mathrm{d}}$, Daniela Basso ${ }^{\mathrm{a}}$, Stephanie Stainbank ${ }^{\mathrm{e}}$, \\ Silvia Spezzaferri ${ }^{\mathrm{e}}$, Torin Cannings ${ }^{\mathrm{f}}$, Giovanni Bianucci ${ }^{\mathrm{b}}$ \\ a Dipartimento di Scienze dell'Ambiente e del Territorio e di Scienze della Terra, Università di Milano-Bicocca, 20126, Milano, Italy \\ b Dipartimento di Scienze della Terra, Università di Pisa, via Santa Maria 53, 56126, Pisa, Italy \\ ${ }^{\mathrm{c}}$ Museo di Storia Naturale, Università di Pisa, via Roma 79, Calci, 56011, Italy \\ ${ }^{\mathrm{d}}$ Scuola di Scienze e Tecnologie, Università di Camerino, via Gentile III da Varano, 62032, Camerino, Italy \\ ${ }^{\mathrm{e}}$ Department of Geosciences, University of Fribourg, Chemin du Musée 6, 1700, Fribourg, Switzerland \\ ${ }^{\mathrm{f}}$ School of GeoSciences, University of Edinburgh, Kings Buildings, West Mains Road, Edinburgh, EH9 3JW, United Kingdom
}

\section{A R T I C L E I N F O}

\section{Keywords:}

Lepidocyclina

Large benthic foraminifera

Eocene

Nepionic acceleration

Paracas Formation

Los Choros Member

\begin{abstract}
A B S T R A C T
Lepidocyclinids are one of the most common group of Cenozoic large benthic foraminifera and, thanks to their clear evolutionary patterns, they are extensively used in biostratigraphy. They originated during the Eocene in the American region and then spread eastward, reaching a worldwide distribution in the Oligocene. This paper investigates the southernmost population of lepidocyclinids ever found along the Pacific coast of South America, located in the lower part of the Paracas Formation (Los Choros Member) of the East Pisco Basin of Peru. The examined Los Choros strata are composed of mixed siliciclastic-bioclastic coarse-grained deposits. The skeletal assemblage is dominated by large benthic foraminifera and mollusks with subordinate echinoids and barnacles, suggesting a deposition in a shallow, tropical, shelf environment with a moderate nutrient supply. The large benthic foraminiferal assemblage is largely dominated by Lepidocyclina rdouvillei. This species is extremely primitive, exhibiting ancestral characters such as a straight wall separating the protoconch and deuteroconch, very large principal auxiliary chambers and a poorly organized equatorial plane. The presence of common and primitive L. rdouvillei, supported by the associated occurrence of Polylepidina, suggests an age comprised between 43.6 Ma and 40.5 Ma for the Los Choros Member in the study area. This range is confirmed by nannofossil assemblages that indicate an age between $42.37 \mathrm{Ma}$ and $40.34 \mathrm{Ma}$ for the base of the overlying Yumaque Member of the Paracas Formation. These results highlight the potential of lepidocyclinids for biostratigraphy and paleoenvironmental reconstructions in South America.
\end{abstract}

\section{Introduction}

Lepidocyclinids are among the most common and widespread Cenozoic large benthic foraminifera (BouDagher-Fadel and Price, 2010). They originated from an asterigerinoid ancestor (probably an Amphistegina-like form) during the early Lutetian within the American bioprovince (Adams, 1987; Butterlin, 1990; BouDagher-Fadel and Price, 2010). During the early Oligocene, they spread to Western Africa and from there they rapidly dispersed along the coasts of the entire Tethys (BouDagher-Fadel and Price, 2010). Most of the American species went extinct between the end of the Oligocene and the end of the early Miocene (BouDagher-Fadel and Price, 2010). Likewise, most of the Mediterranean species went extinct at the end of the early Miocene; however, it has been proposed that some of them survived into the middle Miocene (Adams, 1976; BouDagher-Fadel and Price, 2010). On the contrary, Indo-Pacific lepidocyclinids thrived throughout the Miocene and possibly further on, extending into the Pliocene (Hallock et al., 2006; BouDagher-Fadel and Price, 2010). Since lepidocyclinids are robust biostratigraphic and paleobiogeographical markers, they have been extensively described and studied in the last century. However, while a large number of detailed studies have investigated the Mediterranean and Indo-Pacific bioprovinces, information on African, North

\footnotetext{
* Corresponding author.

E-mail address: giovanni.p.m.coletti@gmail.com (G. Coletti).
} 
American and South American regions are still underrepresented (de Mello e Sousa et al., 2003; Robinson, 2004; Serra-Kiel et al., 2007; BouDagher-Fadel and Price, 2010; Baumgartner-Mora and Baumgartner, 2016; Cotton et al., 2018). To improve our knowledge of lepidocyclinids evolution and distribution, this paper investigates an Eocene section of the lower member of the Paracas Formation (Los Choros Member), in the East Pisco Basin (southern Peru), providing the first detailed biometric study of South American lepidocyclinids. This primitive population represents the southernmost documented occurrence of lepidocyclinids along the Pacific coast of South America; as such, its characterization is crucial for reconstructing the early history of this group of large benthic foraminifera, as well as for biostratigraphic correlation. Furthermore, their presence in the Los Choros Member allows us to date these shallow-marine deposits, which have been poorly constrained up to now due to the lack of planktonic microfossils, thus improving our overall understanding of the Paleogene sequences of the East Pisco Basin.

\section{Geological setting}

The East Pisco Basin is the on-land portion of one of the several Cenozoic forearc basins located along the Peruvian coast (Fig. 1A), and it is widely known thanks to its abundant and exceptionally preserved record of fossil vertebrates from both the Paleogene (Clarke et al., 2007, 2010; Uhen et al., 2011; Lambert et al., 2017b, 2019; Martínez-Cáceres et al., 2017; Muizon et al., 2019) and the Neogene (e.g. Bianucci et al., 2015, 2016a,b, 2018, and previous references therein; Lambert et al., 2014, 2015, 2017a, c; Landini et al., 2017,b, 2019; Marx et al., 2017a, b; Gioncada et al., 2018a, b). Sedimentation in the East Pisco Basin was active from the Eocene to the Pliocene (Dunbar et al., 1990; DeVries, 1998). After the Pliocene, the basin emerged due to uplift caused by the subduction of the Nazca Ridge beneath the South American plate (Macharé and Ortlieb, 1992; Hampel, 2002). The basement consists of a complex assemblage of lower Paleozoic gabbroic to granitoid rocks forming the San Nicolás batholith (Mukasa and Henry, 1990); the latter intrudes a Precambrian metamorphic complex known as the Arequipa massif and is covered by Jurassic volcanic-sedimentary rocks of the Guaneros Formation (León et al., 2008). Three sedimentary units, separated by major basin-wide unconformities, comprise the Eocene succession of the East Pisco Basin (Fig. 1B). These are, from the oldest to the youngest, the Caballas Formation, the Paracas Formation and the Otuma Formation (DeVries, 2017; DeVries et al., 2017; DeVries and Jud, 2018) (Fig. 1B). The Caballas Formation consists of continental to marine transitional deposits, and based on mollusk assemblages has been tentatively placed in the early Eocene (DeVries, 2017, 2018). The Paracas Formation represents a major cycle of marine transgression (Dunbar et al., 1990; DeVries, 2017). The basal portion of this formation, which is the focus of this study, consists of conglomerates and sandstones and is known as the Los Choros Member. The age of the Los Choros Member is still poorly constrained, especially in the study area; it has been tentatively placed in the middle to late Eocene based on foraminiferal and macrofossil assemblages (Lisson, 1925; Rivera, 1957; Tsuchi et al., 1988; Dunbar et al., 1990; León et al., 2008). The upper part of the overlying Paracas Formation, the Yumaque Member, is composed of silty sandstones rich in marine microfossils and deposited between the late Lutetian and the Priabonian (Dunbar et al., 1990; DeVries, 1998; DeVries et al., 2006; Lambert et al., 2017b, 2019). In the study area (Fig. 1C) the Los Choros Member lies directly on the metamorphic basement of the basin and it is composed of mixed siliciclasticbioclastic deposits and a skeletal assemblage characterized by common large benthic foraminifera (Morales et al., 2010, 2013).

\section{Lepidocyclinid taxonomic and evolutionary background}

Lepidocyclinids exhibit two main evolutionary processes: "Embryonic Acceleration" and "Nepionic Acceleration" (van der Vlerk, 1923; Tan Sin Hok, 1932; Drooger, 1993; Schiavinotto, 1995). The former consists of an increase in the degree of embracement of the first chamber (i.e. the protoconch; Fig. 2A) by the second chamber (i.e. the deuteroconch; Fig. 2A) (e.g. Schiavinotto, 1995; Benedetti, 2014). The latter involves reaching the adult stage faster by reducing the number of chambers of the juvenile stage (i.e. the nepionic stage, which comprises all the elements created after the protoconch and the deuteroconch and before the first complete ring of equatorial chamberlets) (van der Vlerk, 1923; Tan Sin Hok, 1932; Drooger, 1993; Adams, 1987; Benedetti, 2014). Both processes essentially seek to reduce the number of steps necessary to reach cyclical organization (i.e. radial symmetric growth). Although this trend is not universally valid and stagnant phases, reversals and environmental influences are possible (e.g. Drooger, 1984; BouDagher-Fadel and Price, 2010; Benedetti and Pignatti, 2013; Bendetti, 2015), it still allows the different species of lepidocyclinids to be clearly separated from each other and used for biostratigraphic and paleobiogeographical purposes.

The earliest lepidocyclinids were characterized by a spiral organization, which was inherited from their asterigerinoid ancestor (Adams, 1987; BouDagher-Fadel and Price, 2010). In the most primitive genera (Helicostegina and Helicolepidina), this spiral organization persists throughout the entire test (Adams, 1987). In more advanced genera, such as Eulinderina and Polylepidina, the spiral organization characterizes only the nepionic stage, after which cyclical organization prevails. Polylepidina, arguably the most evolved genus of spirally-arranged lepidocyclinids (Adams, 1987), is characterized by the development of a principal auxiliary chamber (hereinafter called PAC; Adams, 1987; Tan Sin Hok, 1935) (Fig. 2). The PAC is a displaced third chamber, resting equally on both the deuteroconch and protoconch, and is characterized by two basal openings (Adams, 1987). Two spires initiate from these openings and subsequently surround the embryo (Adams, 1987). The most advanced species of Polylepidina have two PACs (the least advanced only have one), one on each side of the embryo. These PACs are asymmetric, and from each one start two unequally developed spires (Adams, 1987). In the genus Lepidocyclina, the PACs are symmetric and originate four equally developed spires (Adams, 1987) (Fig. 2B). Subsequent evolutionary advancements are mainly achieved through modifications of the deuteroconch. In Lepidocyclina, the protoconch and deuteroconch have the same size and shape, while in the more advanced genera (Nephrolepidina and Eulepidina) the deuteroconch becomes wider and envelops the protoconch. Furthermore, in Nephrolepidina and Eulepidina the deuteroconch is equipped with a series of chamberlets known as auxiliary chamberlets (hereinafter called ACIIs) (Fig. 2A). Following Hottinger (2006), the ACIIs should be considered chamberlets since they were most likely created during a single step of growth of the test. The ACIIs are characterized by a direct connection to the deuteroconch and from each one, two short spire originate to subsequently surround the embryo. Over time in Nephrolepidina the protoconch becomes more enclosed by the deuteroconch and the number of ACIIs increases. In Eulepidina, the protoconch is always almost entirely enveloped by the deuteroconch and ACIIs occur in large numbers and across the entire surface of the deuteroconch (i.e. they are not confined to the equatorial plane) (Adams, 1987). In the most advanced forms of Eulepidina, even the short spires originating from the ACIIs are missing and cyclical organization dominates the test from the very beginning of its development (Adams, 1987). Lepidocyclinids also display a further pattern of evolution that involves the disposition of equatorial chamberlets, the 

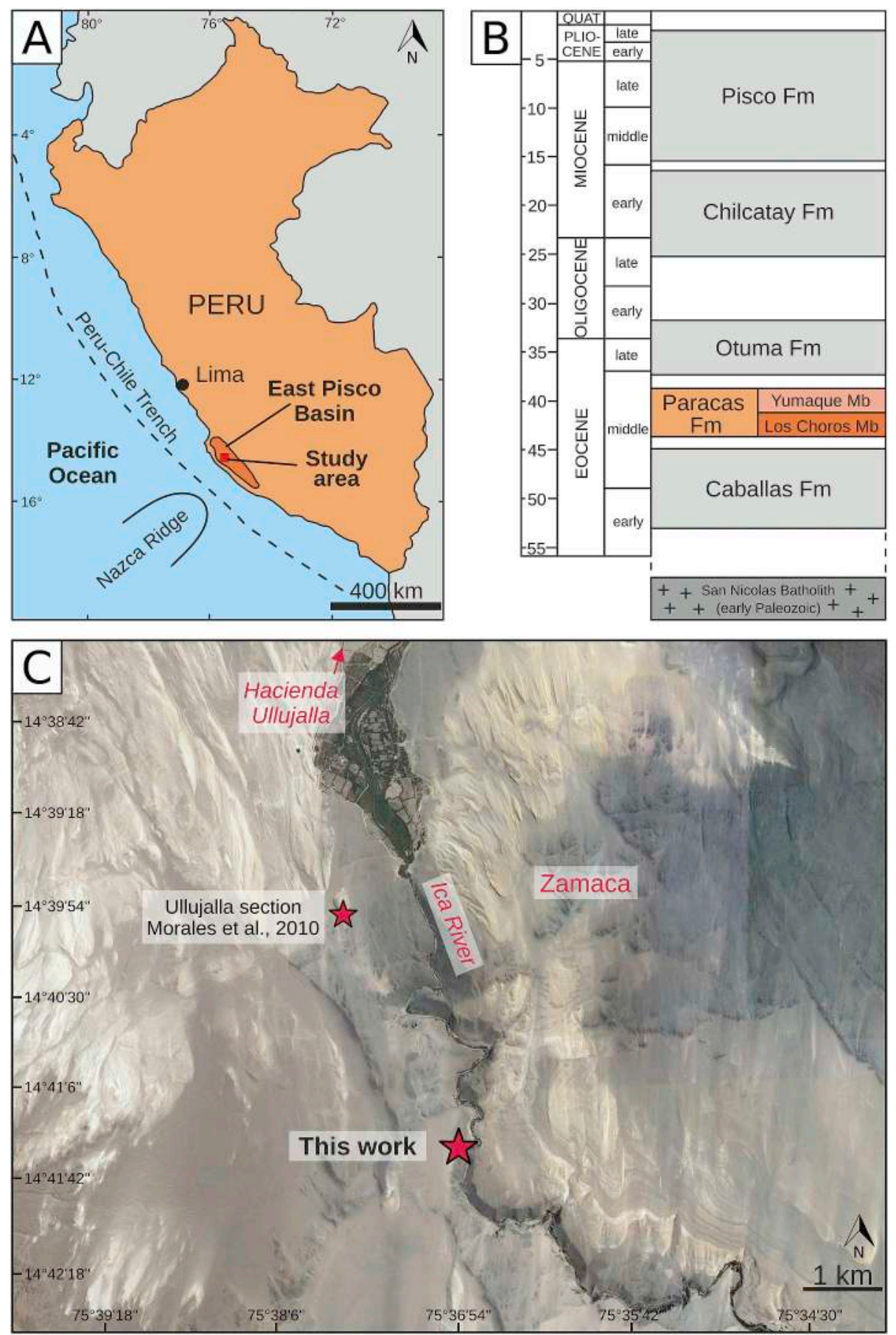

Fig. 1. Location of the study area and stratigraphic overview of the East Pisco Basin. A) Location of the East Pisco Basin and of the study area along the Peruvian coast, modified from Di Celma et al. (2018a). B) Schematic stratigraphic log of the East Pisco Basin sedimentary succession, redrawn and modified from DeVries et al. (2006) following DeVries and Jud (2018). C) Close-up of the area of Zamaca (Google Earth satellite image, (C) 2018 DigitalGlobe); the stars show the location of the Ullujalla section studied by Morales et al. (2010) and the Zamaca section studied in this work.

"Neanic Acceleration" (Schiavinotto, 1992, 1995; 2010; Benedetti, 2014), which substantially represents the tendency through time to achieve a more efficient packing on the equatorial plane (Benedetti, 2014). This process, although less investigated than Embryonic Acceleration and Nepionic Acceleration, represents an additional, highly useful, instrument to investigate lepidocyclinids evolution (Schiavinotto, 1992, 1995; 2010; Benedetti, 2014).

\section{Methods}

The studied section is located in the Ica Desert $\left(14^{\circ} 41^{\prime} 28.7^{\prime \prime} \mathrm{S}\right.$; $75^{\circ} 36^{\prime} 50.1^{\prime \prime} \mathrm{W}$ ), on the western bank of the Ica River, within the broad Zamaca area (Di Celma et al., 2019; Landini et al., 2019) (Fig. 1). At the study site, a stratigraphic section of the Los Choros deposits was obtained by measuring the thickness of each layer with a Jacob's staff. 

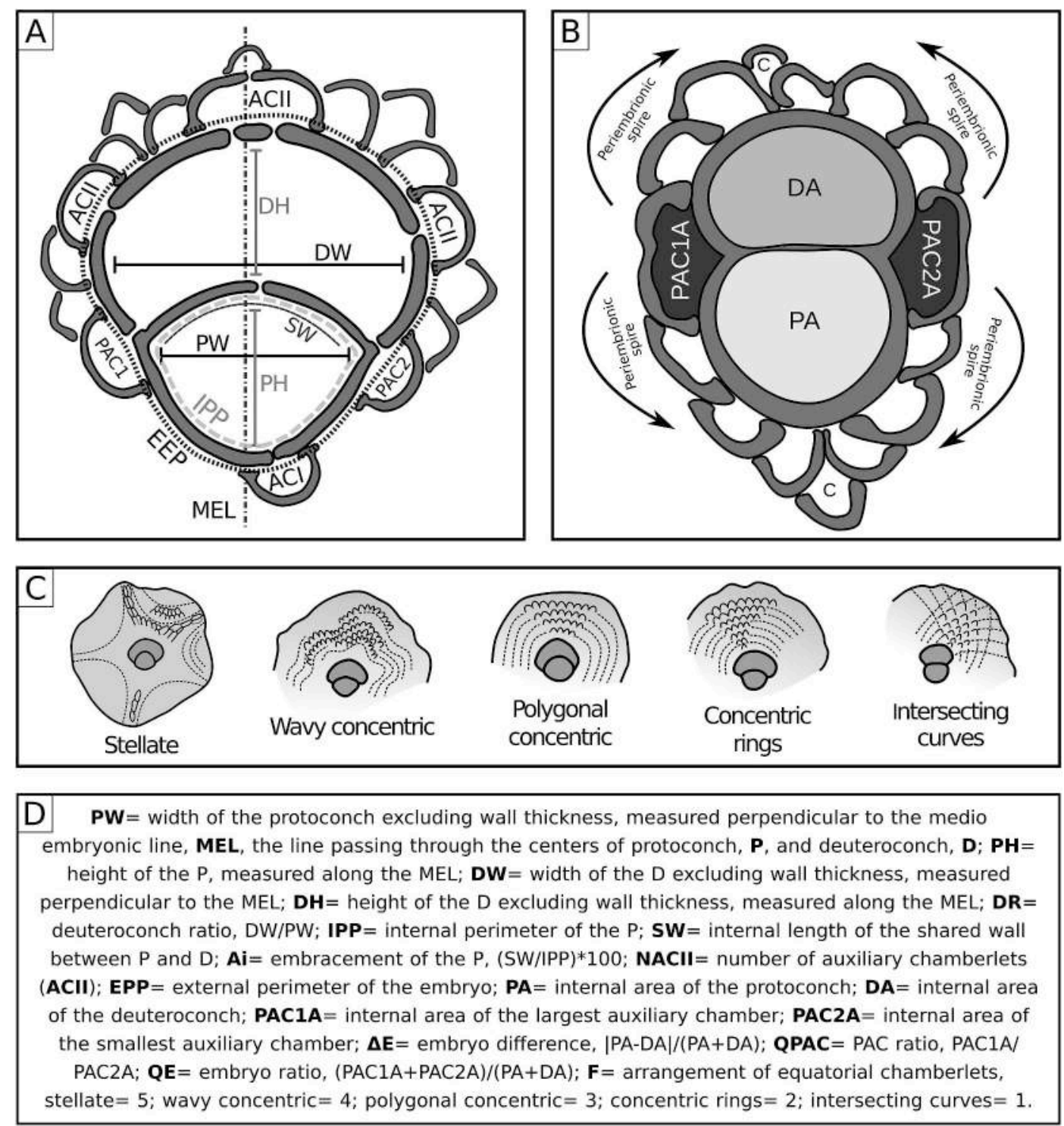

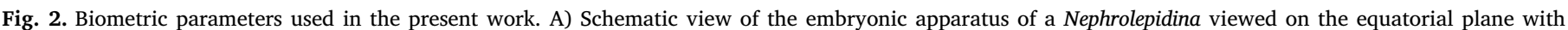

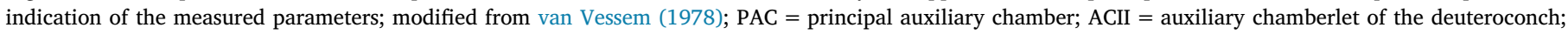

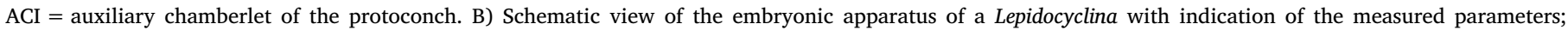

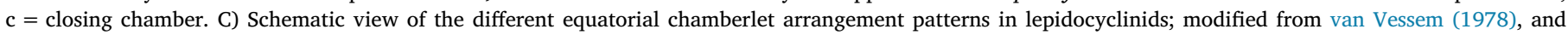
Chaproniere (1980). D) Explanation of the biometric parameters used in the present analysis.

Lithology, grain-size, texture, composition, sedimentary structures and macrofossil content were described for each layer. Nine rock samples (For1 to For9) were collected along the investigated section. Wherever possible, specimens of lepidocyclinids were isolated from these samples and studied in dedicated thin sections. Further thin sections were prepared from each rock sample in order to analyze the composition of the skeletal assemblage and the axial sections of lepidocyclinids. The skeletal assemblages were assessed based on visual comparison charts for percentage estimation (Baccelle and Bosellini, 1965; Flügel, 2010). Thin sections were studied through a Leica Leitz Laborlux $S$ transmitted light optical microscope at the Università di Milano-Bicocca.

Further samples were collected from the overlying Yumaque Member to stratigraphically constrain the upper boundary of the Los Choros deposits through nannofossil biostratigraphy. Calcareous nannofossils were examined from six rock samples collected from a few meters (ZA2) to approximately $20 \mathrm{~m}$ (ZA7) above the base of the Yumaque Member. All the samples were prepared as standard smear slides (Bown and Young, 1998) and analyzed under an Olympus BX50 cross-polarized light microscope at 1000x. Nannofossil taxonomy follows Perch-Nielsen (1985), Bown (1998) and Nannotax3 (Young et al., 2019). Biozonation is after Agnini et al. (2014), with reference to Martini (1971). Total calcareous nannofossil abundance in each slide was qualitatively assessed as percentage of sediment particles and defined as common $(\mathrm{C}=10-50 \%)$, few $(\mathrm{F}=1-10 \%)$, rare $(\mathrm{R}<1 \%)$ and barren $(\mathrm{B}=$ no specimens). Individual calcareous nannofossil taxa abundance was recorded as a function of their abundance per field of view (FOV) as common ( $\mathrm{C}>1-10$ specimens/FOV), few ( $\mathrm{F}=1$ specimen/1-10 FOV), rare ( $R<1$ specimen/10 FOV) and very rare (VR $=1$ specimen/transverse). Calcareous nannofossil preservation was recorded as moderate $(\mathrm{M}=$ primary morphological characteristics 
somewhat altered but most specimens identifiable at the species level), poor ( $\mathrm{P}=$ specimens were etched or overgrown), or intermediate ( $\mathrm{M}$ / P).

Since preliminary analyses revealed that secondary calcite filled the embryonic chambers of the Los Choros lepidocyclinids, we chose to investigate these specimens in thin section rather than by computed tomography (CT). Initially, a total of 150 randomly selected, lepidocyclinid specimens were isolated from the rock samples. Each specimen was embedded in epoxy resin within a pill blister and abraded with silicon carbide to expose its equatorial plane. Subsequently, the specimens were glued on a standard thin section glass and prepared into thin sections. Each specimen was identified by a label indicating the rock sample (For 1 to 9), the thin section (A to Z) and the position on the thin section (1-6). All the thin sections are stored in the Department of Earth and Environmental Sciences of Milano-Bicocca. Overall, 51 specimens provided well-preserved and almost perfectly oriented equatorial sections.

Since presently there are no biometric studies of South American lepidocyclinids, in order to properly understand the evolutionary significance of the morphological characteristics of the Los Choros specimens we have compared our material with two primitive populations of the Oligocene of the Tethys. The Cyprus population represents an example of a primitive lepidocyclinid population of the Mediterranean bioprovince (Robertson et al., 1991; Banner et al., 1999). It consists of 23 lepidocyclinid specimens prepared as thin sections, from which 11 present suitable equatorial sections. The Maldives population represents an example of a primitive lepidocyclinid population of the Indo-Pacific bioprovince (Betzler et al., 2017; Coletti et al., 2018a). It consists of nine specimens investigated with computed tomography following the methodology proposed by Coletti et al. (2018a). On the equatorial plane, for all populations, various biometric parameters were measured in order to distinguish and identify the different species of lepidocyclinids (Tan Sin Hok, 1932; Drooger and Socin, 1959; van der Vlerk, 1959, 1963; Matteucci and Schiavinotto, 1977; Schiavinotto, 1979; Chaproniere, 1980; Drooger, 1993; Özcan et al., 2009; Hohenegger, 2011; Benedetti and Pignatti, 2013; Torres-Silva et al., 2017; Briguglio, 2018) (Fig. 2). For each specimen, the measured morphological elements were the following: the two diameters (the one perpendicular and the one parallel to the medio-embryonic line) of the protoconch (PW, $\mathrm{PH}$ ) and of the deuteroconch (DW, DH); the area of the protoconch (PA), of the deuteroconch (DA) and of the PACs (PAC1A, PAC2A); the external perimeter of the embryo (EEP); the internal perimeter of the protoconch (IPP); the length of the shared wall that separates the protoconch from the deuteroconch (SW); the number of ACIIs (NACII) (Fig. 2). For each of the specimens the arrangement of the equatorial chamberlets was also evaluated using the $\mathrm{F}$ parameter of Chaproniere (1980) (Fig. 2). These parameters were used to calculate important biometric indexes like the deuteroconch ratio (DR; calculated as DW/PW) and the degree of embracement of the protoconch (Ai, calculated as the ratio SW/IPP). In addition to the above commonly used parameters, new ones were introduced. Firstly, the sum of DH and PH was calculated to better compare our Peruvian specimens with those of other areas of South America described in scientific papers of the late thirties (e.g. Todd and Barker, 1932), where the authors used to present just the diameters of the whole embryo (i.e. the largest between DW and $\mathrm{PW}$ and $\mathrm{DH}+\mathrm{PH})$. Since primitive lepidocyclinids have a similarly sized protoconch and deuteroconch, in order to properly evaluate the size difference between the two chambers we introduced the parameter "embryo difference " $(\Delta \mathrm{E})$. This parameter is calculated as the ratio between the absolute value of the difference between the area of the two chambers and the total area of the embryo (Fig. 2). Furthermore, since one of the major differences between the most advanced species of Polylepidina and the most primitive species of Lepidocyclina is that the former have asymmetric PACs, we introduced the parameter QPAC, calculated as the ratio between the area of the two PACs (Fig. 2). Finally, in order to investigate the importance of PACs for separating primitive lepidocyclinid species, we introduced the parameter embryo ratio $(\mathrm{QE})$, calculated as the ratio between the total area of the PACs and the total area of the embryo (Fig. 2).

\section{Results}

\subsection{Lithology and skeletal assemblage}

The lower part of the investigated succession consists of mixed siliciclastic-bioclastic gravel-sized deposits (Fig. 3A and B). At the base there is a poorly sorted breccia deposit that directly overlies the crystalline basement (Fig. 3C). It is composed of angular clasts (centimeterto decimeter-sized and exhibits a fining-upward trend) mixed with few coarse biogenic fragments (Fig. 3C). Higher up, the grain size decreases to fine gravel, sorting improves and biogenic fragments become more common (Figs. 3 and 4A, B). The skeletal assemblage is dominated by large benthic foraminifera (Fig. 3D) and mollusks, with important contributions from barnacles and echinoids (Figs. 3A, 4C-D). Coralline algae are generally rare, except in sample For7 where they are almost as abundant as barnacles. Bryozoans, small benthic foraminifera and brachiopods are very rare. Lepidocyclinids dominate the foraminiferal assemblage (Fig. 5A and B), but Amphistegina is also common in most of the samples (Fig. 5C and D). Orthophragminids are locally abundant (Fig. 5A and B). Nummulitids and small rotaliids are rare (Fig. 5E). Encrusting foraminifera are very rare (Fig. 5F). In most of the samples, foraminifera tests exhibit common orientation and the observed isolated specimens are usally abraded. Nearly half of the isolated foraminifera of samples For5 and For6 belong to the microspheric generation. Generally, the individuals of the megalospheric generation are much more common than those of the microspheric generation (Beavington-Penney and Racey, 2004), however the two groups can be easily separated from each other and concentrated by currents since they have different sizes and weights. Therefore, the prominent abundance of microspheric individuals indicates a good degree of sorting. Mollusks are mainly represented by ostreids (Fig. 4D); most of the observed specimens display significant abrasion and fragmentation. Platy fragments usually exhibit a preferred orientation. Barnacles are represented by primitive acorn taxa lacking parietal tubes (i.e. the longitudinal tubes that extend from the base to the apex of the plates that constitute the shell) (Fig. 6). Barnacle specimens are always disarticulated and abraded (comminuted shell bed of Doyle et al., 1997; Grade 1 and 2 sensu Nielsen and Funder, 2003; Type D preservation sensu Nomura and Maeda, 2008) (Fig. 6A and B); a gastropod predation hole was observed on a specimen (Fig. 6A). Coralline algae are poorly preserved and generally occur as very small fragments. However, a larger specimen, attached to an ostreid, was also observed (Fig. 7). This specimen is characterized by a monomerous construction, a plumose hypothallus and cell fusions (Fig. 7). These coralline algae represent the first specimens ever reported from the East Pisco Basin. Echinoids are mainly represented by regular forms characterized by large and thick spines (Fig. 4D).

The central part of the studied section, is hidden beneath eolian deposits that accumulated in the present-day desert environment (Fig. 3A). The upper part of the section consists of poorly sorted impure sandstones (Figs. 3A and 8A). The biogenic fraction is dominated by benthic foraminifera with important contributions from echinoids and mollusks (Figs. 3 and 8A). Small benthic rotaliids are the most abundant group of foraminifera and among them the genera Nonionon, Loxostomina, Heterolepa, and Bolivina are common (Fig. 8B and C). Lepidocyclinids are also very important (Fig. 8A). Orthophragminids and 


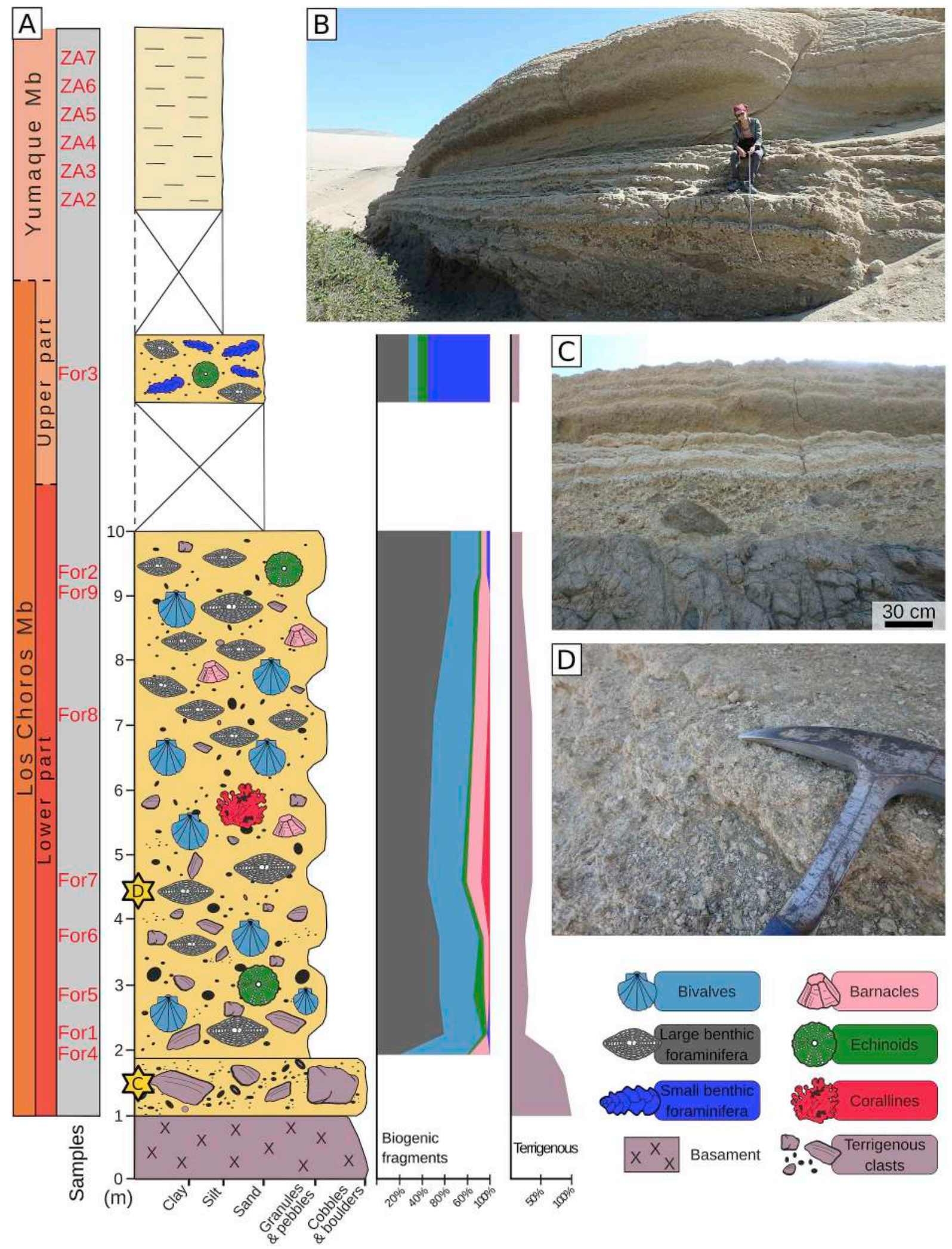

Fig. 3. The measured section of Zamaca, located on the western side of the Ica River. A) Stratigraphic log with sample positions (For1 to For9, ZA2 to ZA7), and indication of grain size and skeletal assemblages; empty spaces in the log represent portions (not to scale) covered by recent eolian deposits; yellow stars indicate the position of the close-ups illustrated in panels C and D. B) Field photograph of the lower part of the measured section. C) Close-up of the nonconformity between the basin basement and the overlying basal breccia of the Los Choros Member. D) Close-up of a foraminifera-rich interval from the lower part of the section. (For interpretation of the references to colour in this figure legend, the reader is referred to the Web version of this article.) 

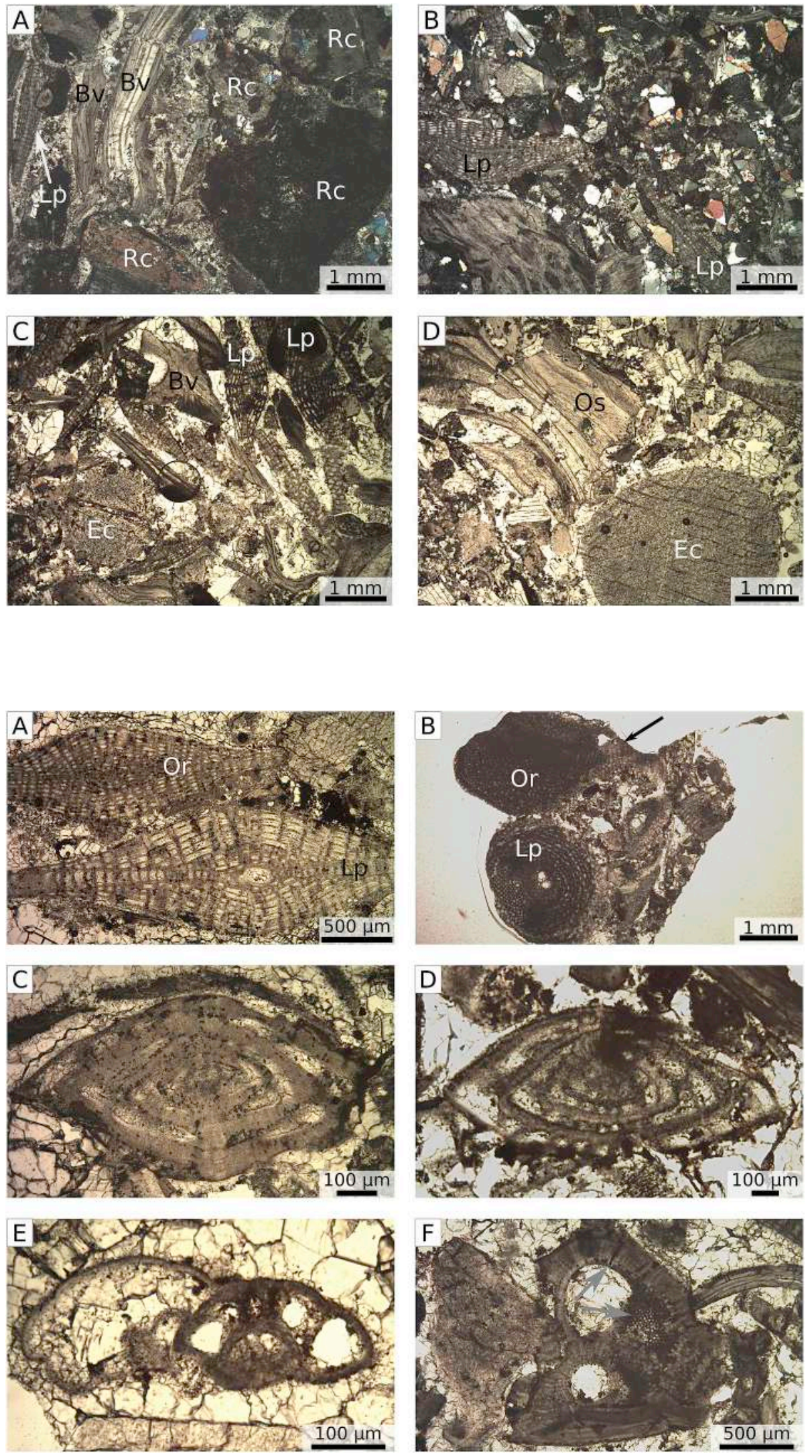

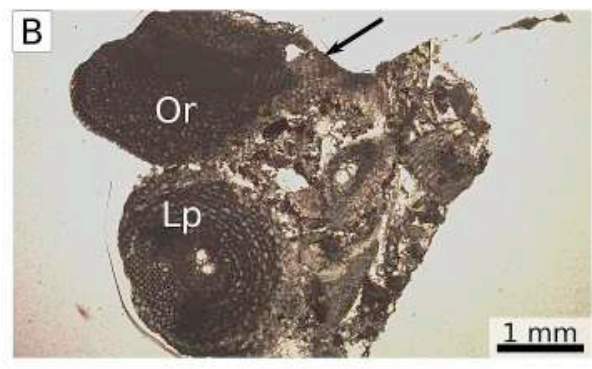

Fig. 4. Skeletal assemblage from the lower part of the Zamaca section. A) Fragments of bivalve shells (Bv) and a lepidocyclinid (Lp) displaying preferential orientation, common rock fragments (Rc); sample For4. B) Large lepidocyclinids (Lp) mixed with siliciclastic grains; sample For7. C) Large lepidocyclinid specimens (Lp) presenting similar orientations, bivalve shells (Bv) and a large spine of a regular echinoid (Ec); sample For5. D) A large ostreid fragment (Os) and a very large spine of an irregular echinoid (Ec); sample For6.

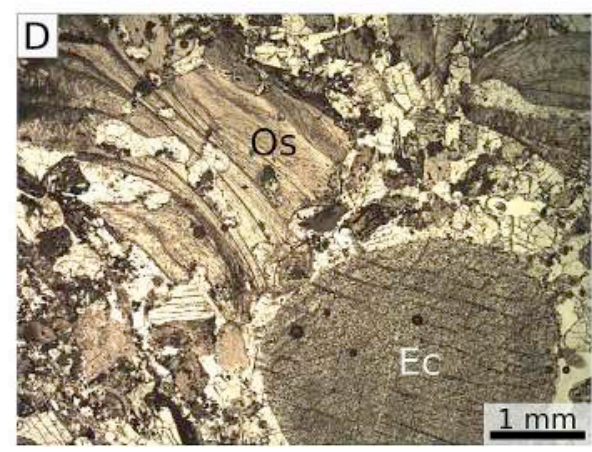

Fig. 5. Foraminiferal assemblage from the lower part of the Zamaca section. A) An orthophragminid (Or) and a Lepidocyclina (Lp); both specimens are cut along the axial section; note the smaller lateral chambers of an orthophragminid; sample For9. B) An orthophragminid (Or) and a Lepidocyclina (Lp); both specimens are cut along pseudo-equatorial sections; arrow = equatorial chamberlets of Discocyclina; sample For2. C) Amphistegina; sample For7. D) Amphistegina; sample For5. E) Small benthic foraminifera, Cibicides?; sample For7. F) Encrusting foraminifera; arrows = foramina; sample For6. 

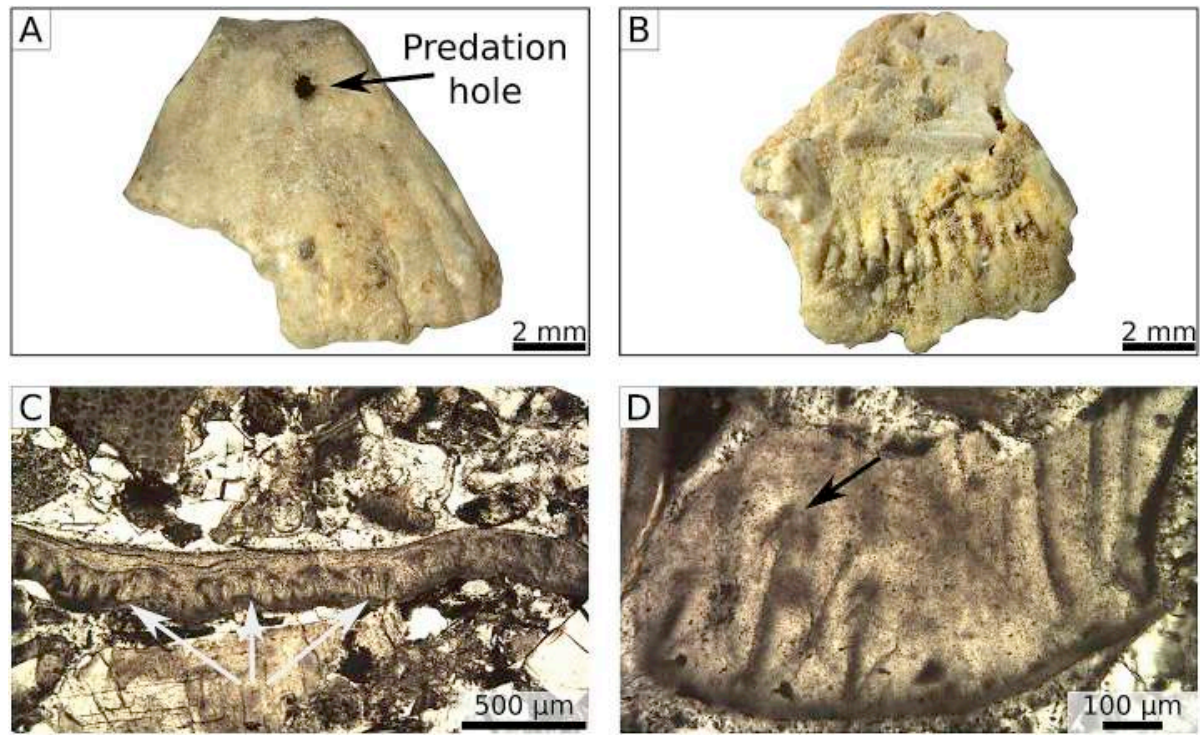

Fig. 6. Barnacles from the lower part of the Zamaca section. A) View of the external surface of a plate; note the predation hole; sample For6. B) View of the internal surface of a plate; note the lack of parietal tubes; sample For6. C) Thin section of a wall plate, note the lack of parietal tubes and the simple intralaminate figures; arrows = intralaminate figures; note the lack of parietal tubes and the simple intralaminate figures; sample For7. D) Detail of the intralaminate figure (black arrow) of a barnacle plate; sample For4. nummulitids are very rare. Isolated specimens of large benthic foraminifera from the upper part of the studied section are usually better preserved than those from the lower part. Echinoids are mostly represented by irregular taxa with thin and hollow spines (Fig. 8D). Rare ostracods also occur (Fig. 8A).

\subsection{Nannofossil assemblage of the Yumaque Member}

Calcareous nannofossil abundance ranges from common to few, with the exception of sample ZA2 that is barren. Their preservation is moderate to poor (Fig. 9). The persistent but rare presence of $R e$ ticulofenestra reticulata from sample ZA3, coupled with its abundance that increases upwards, places the base of the Yumaque Member close to the base of biozone CNE14 (Base common $R$. reticulata $=42.37 \mathrm{Ma}$ ) (Fig. 9). The Base of $R$. stavensis ( $=D$. bisectus in Agnini et al., $2014=40.34 \mathrm{Ma}$ ) is recognized from sample ZA5 upwards and defines the transition to biozone CNE15 (Fig. 9).

\subsection{Lepidocyclinid systematic paleontology}

Nearly all isolated specimens were classified as lepidocyclinids. Among the 51 specimens that exhibited a perfect equatorial section suitable for species level identification, the vast majority were identified as Lepidocyclina rdouvillei. Polylepidina sp. 1 was much less common, whereas Lepidocyclina cf. trinitatis and Polylepidina sp. 2 were extremely rare. No significant assemblage variations were observed among the samples.

\section{Family Lepidocyclinidae Scheffen, 1932}

Genus Lepidocyclina Gümbel, 1870, emend. Adams (1987).

Diagnosis (emended after Adams, 1987) - Test discoidal with a distinct layer of equatorial chamberlets and lateral chamberlets on each side. Megalospheric stage with protoconch and deuteroconch of similar size, separated by an almost straight wall. Embryonic apparatus surrounded by four, short and almost symmetrical periembryonic spires that start from two PACs of similar size. ACIIs do not occur in this genus.
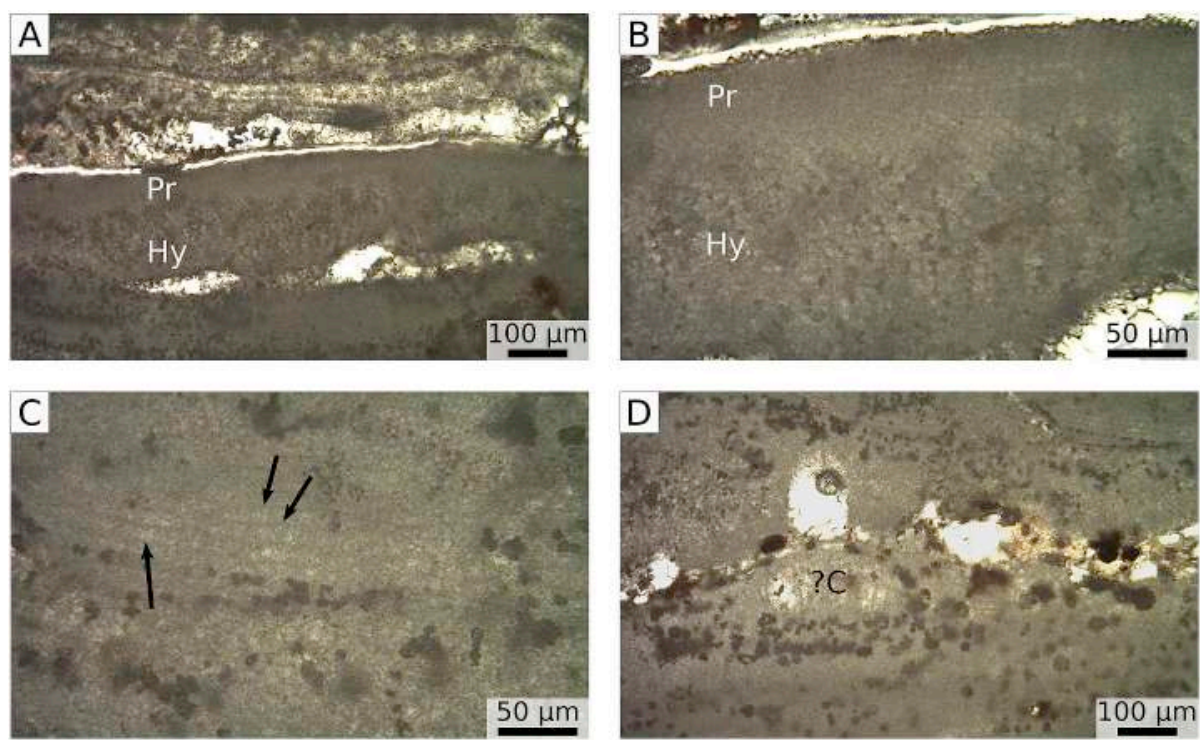

Fig. 7. Coralline algae of sample For7 from the lower part of the Zamaca section. A) Overview of a thallus growing over an oyster fragment; $\operatorname{Pr}=$ perithallus, i.e., the upper portion of a thallus with monomerous construction; Hy = hypothallus, i.e., the lower portion of the thallus, dedicated to the colonization of new substrates. B) Close-up of the same algae as in A, note the plumose structure of the hypothallus; $\mathrm{Pr}=$ perithallus; $\mathrm{Hy}=$ hypothallus. C) Detail of the perithallus showing fusions of cells of adjacent filaments (arrows). D) Detail of a possible reproductive structure, a conceptacle (?C). 

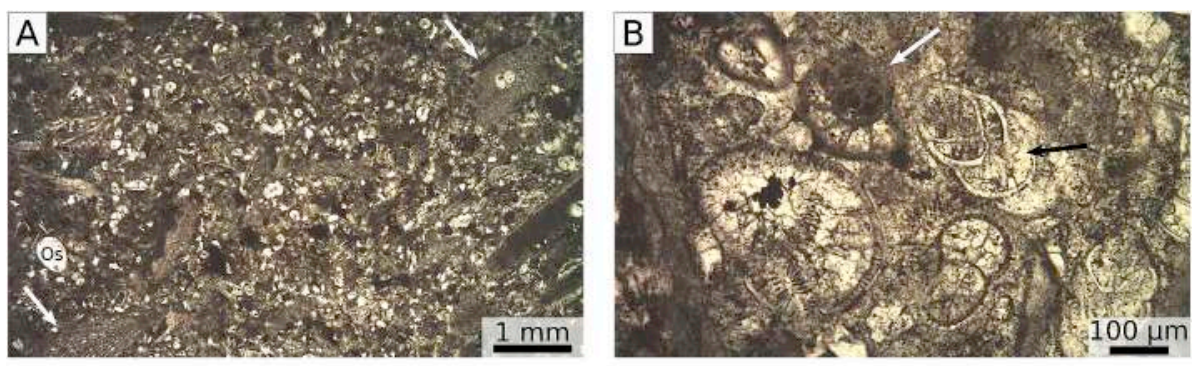

Fig. 8. Skeletal assemblage of the lower part of the Zamaca section. A) Poorly sorted impure bioclastic sandstone; $\quad$ white arrows = lepidocyclinids; Os = ostracods; sample For3. B) Small benthic foraminifera; black arrow = Heterolepa; white arrow = Loxostomina; sample For3. C) Loxostomina; sample For3. D) Black arrows = irregular echinoid spine; Lp = lepidocyclinid; sample For3.
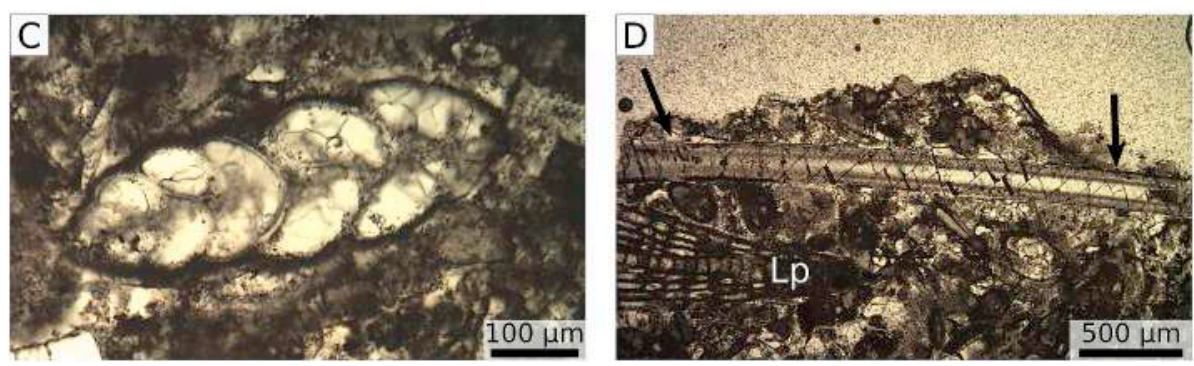

Lepidocyclina rdouvillei Lisson (1921) Fig. 10, Fig. 12A

1921 Lepidocyclina (Isolepidina) R. douvillei Lisson, pl. 3, Figs. 1-3, pl. 4, Fig. 1, pl. 5, Figs. 1-3.

1922 Lepidocyclina (Nephrolepidina) peruviana Cushman, p. 138, pl. 24, Fig. 1.

1928 Lepidocyclina (Isolepidina) R. douvillei Lisson var. armata Rutten, p. 944, Fig. 24f-k, p. 945, Fig. 29, p. 948, pl. 2, Figs. 27-28.

1932 Lepidocyclina (Lepidocyclina) peruviana Todd and Barker, p. 536, pl. XLI, Figs. 1-4, p. 537, pl. XLII, Figs. 2, 3, 5-7.

2003 Lepidocyclina rdouvillei de Mello e Sousa et al. p. 236, pl. 2, Fig. 1.

2010 Lepidocyclina (Lepidocyclina) peruviana Morales et al. p. 239, pl. 1, Figs. 1-6.

Material - 9 equatorial sections of megalospheric specimens from sample For1; 5 equatorial sections of megalospheric specimens from sample For2; 11 equatorial sections of megalospheric specimens from sample For3; 3 equatorial sections of megalospheric specimens and 6 equatorial sections of microspheric specimens from sample For5; 2 equatorial sections of megalospheric specimens and 1 equatorial section of a microspheric specimen from sample For6; 1 equatorial section of a megalospheric specimen from sample For8; 5 equatorial section of megalospheric specimens from sample For9; more than one hundred of sub-equatorial, tangential and axial section of specimens from samples For1 to For9.

Emended diagnosis - Test lenticular (Fig. 10A and B). Embryonic apparatus small (the largest diameter of the embryo is on average less than $300 \mu \mathrm{m}$ ), with protoconch and deuteroconch roughly similar in size (isolepidine embryo) (Fig. 10C-E). PACs are large compared to the size of the embryo (roughly between $1 / 10$ and $1 / 5$ of the total area of the embryo) (Fig. 10C). Embryonic apparatus surrounded by slightly irregular chamberlets, often larger than the regular chamberlets of the equatorial plane (Fig. 10D). Regular equatorial chamberlets, arcuate in shape and disposed in patterns of intersecting curves $(\mathrm{F}=1)$ (Fig. 10E). Lateral chamberlets arranged in a spiral pattern (Fig. 10F).

Description - The test is lenticular, $2-4 \mathrm{~mm}$ in diameter, biconvex and flattened toward the periphery (Fig. 9A and B). The external surface presents very faint pustules, only observable on well-preserved tests. The embryo of megalospheric specimens is relatively small (PW:

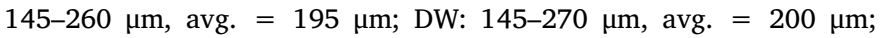

PH + DH: 205-370 $\mu \mathrm{m}$, avg. $=285 \mu \mathrm{m})$, with the protoconch and the deuteroconch roughly similar in size $(\Delta \mathrm{E}: 1-48 \%$, avg. $=14 \%)$ (Table 1). The deuteroconch does not embrace the protoconch (Ai: $16-32 \%$, avg. $=25 \%$ ) and the wall that separate these two chambers is almost straight (Table 1; Fig. 10C-E). Two PACs of roughly the same size (QPAC: $1-1.9$, avg. $=1.3$ ) can be observed on both sides of the embryo (Table 1; Fig. 10E). Both PACs are relatively large and their cumulative area is roughly $20 \%$ of the embryonic area (QE: 6-35\%, avg. $=20 \%$ ) (Table 1; Fig. 10E). The position of the PACs is often nonsymmetrical with respect to the wall that separates the protoconch from the deuteroconch (Fig. 10E). Four roughly symmetrical spires of periembryonic chamberlets originate from these PACs and surround the embryo (Fig. 10D). ACIIs were not observed. The periembryonic spires are surrounded by an area of slightly irregular chamberlets, which are larger than the regular chamberlets of the equatorial plane; this area extends for roughly $200 \mu \mathrm{m}$ around the embryo (Fig. 10D). The regular chamberlets of the equatorial plane are arcuate to ogival in shape and disposed in a pattern of intersecting curves $(\mathrm{F}=1$ ) (Table 1; Fig. 10E). The lateral chamberlets are arranged in a spiral pattern, observable on tangential sections of the test (Fig. 10F).

The specimens of the microspheric generation are slightly larger than those of the megalospheric generation and present a similar external morphology. The protoconch is very small (around $10 \mu \mathrm{m}$ ) and is followed by approximately six spirally-arranged chambers (Fig. 10G and $\mathrm{H}$ ). The eighth chamber has two openings each connecting to two different chamberlets (Fig. 10G and H). Following the eighth chamber, the spiral organization is rapidly replaced by cyclical organization (Fig. 10G and H).

Remarks - The specimens examined in perfect equatorial sections $(\mathrm{n}=36)$ have rather constant biometric parameters in the different samples and exhibits an unimodal distribution of embryonic parameters. This suggests that they comprise a homogeneous population referable to a single species.

In the original description by Lisson (1921), this species is named Lepidocyclina (Isolepidina) $R$. douvillei. The " $R$ " stands for Robert, the name of the French paleontologist Robert Douville (1881-1914) after which the species is named (Lisson, 1921; Todd, 1933). This species is identified in the literature both as Lepidocyclina douvillei and as Lepidocyclina rdouvillei (e.g. Butterlin, 1990; de Mello e Sousa et al., 2003). In particular, the former spelling is presently reported on the World 


\begin{tabular}{|c|c|c|c|c|c|c|c|c|c|c|c|c|c|c|c|c|c|c|c|c|c|c|c|c|c|c|c|c|c|c|c|c|c|c|c|}
\hline$\frac{\frac{d}{O}}{\frac{0}{E}}$ & 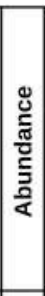 & 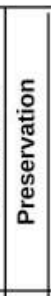 & 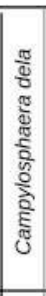 & 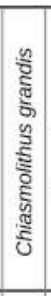 & 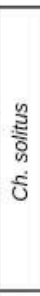 & 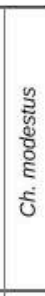 & 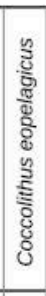 & $\begin{array}{l}5 \\
0 \\
0 \\
\text { है } \\
\text { D } \\
ن \\
ن\end{array}$ & 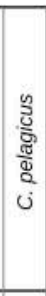 & 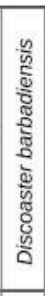 & 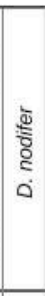 & 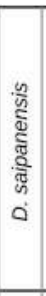 & 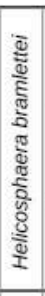 & 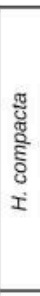 & 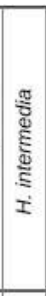 & 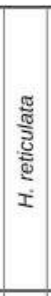 & 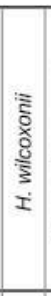 & 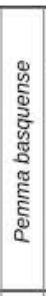 & 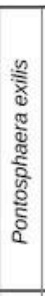 & 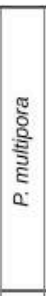 & 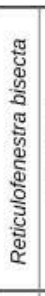 & 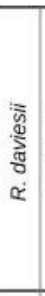 & 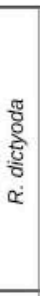 & 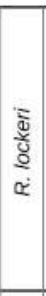 & $\begin{array}{l}\frac{\pi}{\pi} \\
\frac{\pi}{3} \\
\frac{\tilde{z}}{2} \\
\alpha \\
\alpha\end{array}$ & 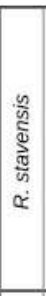 & 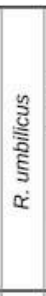 & 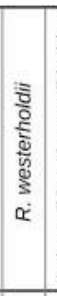 & 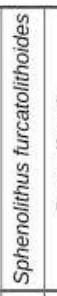 & $\begin{array}{l}\text { है } \\
\text { है } \\
\text { है } \\
\text { vi }\end{array}$ & $\begin{array}{l}\text { है } \\
\text { क्ष̃ } \\
\text { vi }\end{array}$ & $\begin{array}{l}\bar{\Xi} \\
\text { ș } \\
\text { के } \\
\text { ci }\end{array}$ & 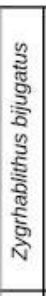 & 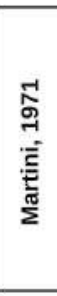 & 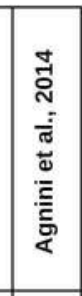 \\
\hline ZA7 & C & $\mathrm{M}$ & $R$ & $\mathrm{R}$ & $\mathrm{R}$ & VR & $\mathrm{F}$ & C & $\mathrm{F}$ & & VR & & $\mathrm{F}$ & $\mathrm{R}$ & $\mathrm{R}$ & $\mathrm{R}$ & VR & & $\mathrm{R}$ & & $R$ & & $\mathrm{R}$ & & $\mathrm{CF}$ & $R$ & & R & & $\mathrm{F}$ & $\mathrm{F}$ & $\mathrm{F}$ & $\mathrm{R}$ & \multirow{6}{*}{$\begin{array}{l}\text { NP } \\
16\end{array}$} & \multirow{3}{*}{$\begin{array}{c}\text { CNE } \\
15\end{array}$} \\
\hline ZA6 & $F / C$ & B & & & & & R & & & & & & & & & VR & & & & & $\mathrm{R}$ & & C & & & $\mathrm{R}$ & & $R$ & & & VR & & & & \\
\hline ZA5 & $R$ & $M$ & & VR & $\mathrm{F}$ & VR & R & R & $\mathrm{R}$ & & & & & & & & & & $\mathrm{R}$ & VR & $F$ & & C & VR & $\mathrm{F}$ & $R$ & $\mathrm{~F}$ & $\mathrm{~F}$ & & VR & & & & & \\
\hline ZA4 & $F$ & MB & & $R$ & $\mathrm{~F}$ & & $\mathrm{~F}$ & $R$ & C & & & $\mathrm{R}$ & & & & & & & & & & & $\mathrm{C}$ & & $\mathrm{F}$ & & $R$ & VR & & VR & & & & & \multirow{3}{*}{$\begin{array}{c}\text { CNE } \\
14\end{array}$} \\
\hline ZA3 & $F$ & $M$ & & & $\mathrm{~F}$ & VR & $\mathrm{F}$ & $\mathrm{F}$ & $\mathrm{F}$ & $R$ & & $\mathrm{R}$ & & & & & & $\mathrm{R}$ & & & & $R$ & $\mathrm{C}$ & $\mathrm{R}$ & $\mathrm{R}$ & & $\mathrm{F}$ & & VR & VR & & & & & \\
\hline ZA2 & B & & & & & & & & & & & & & & & & & & & & & & & & & & & & & & & & & & \\
\hline
\end{tabular}
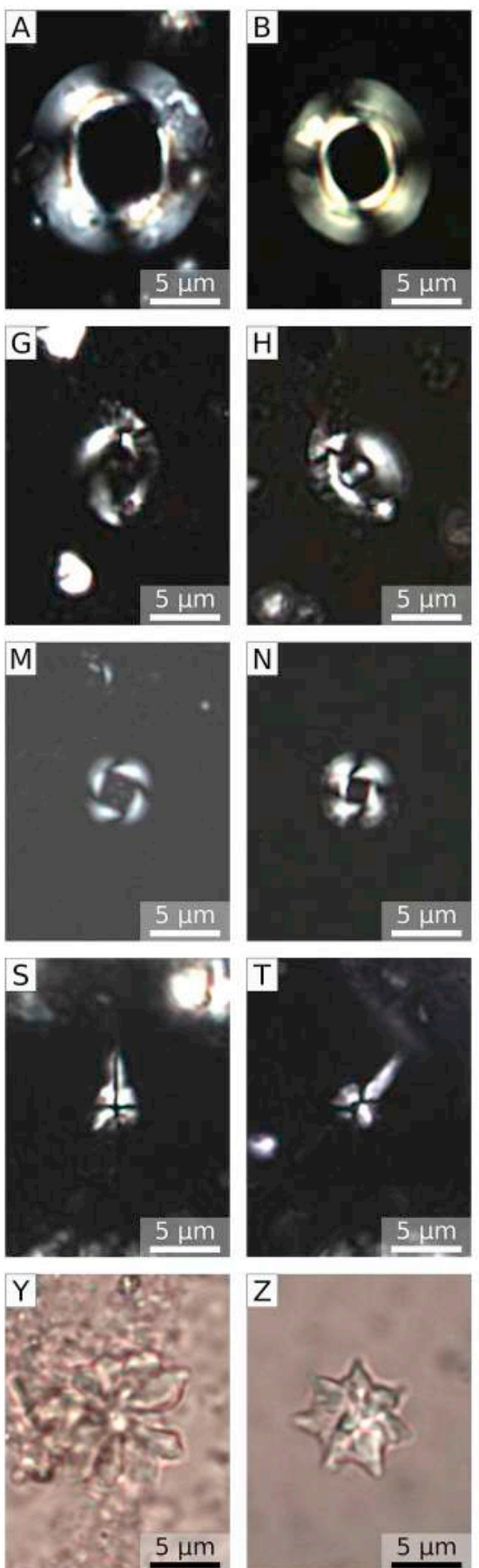

$5 \mu \mathrm{m}$
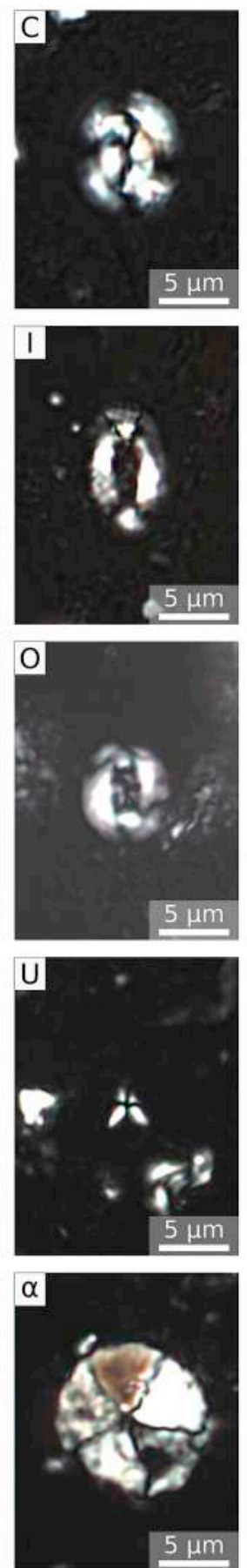
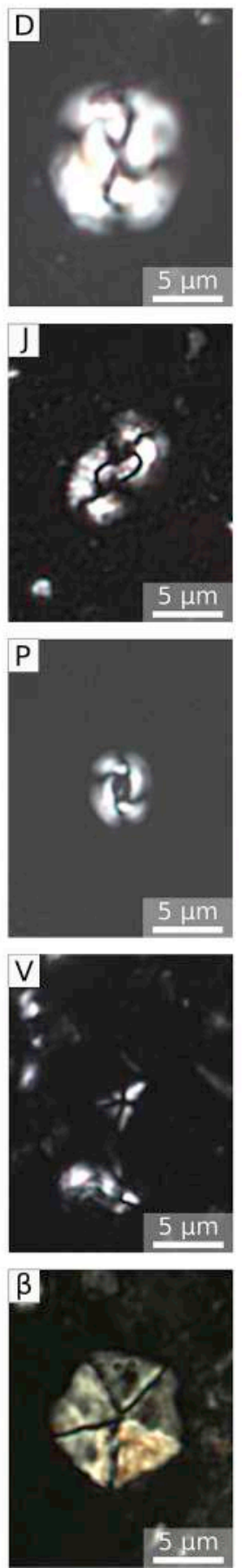
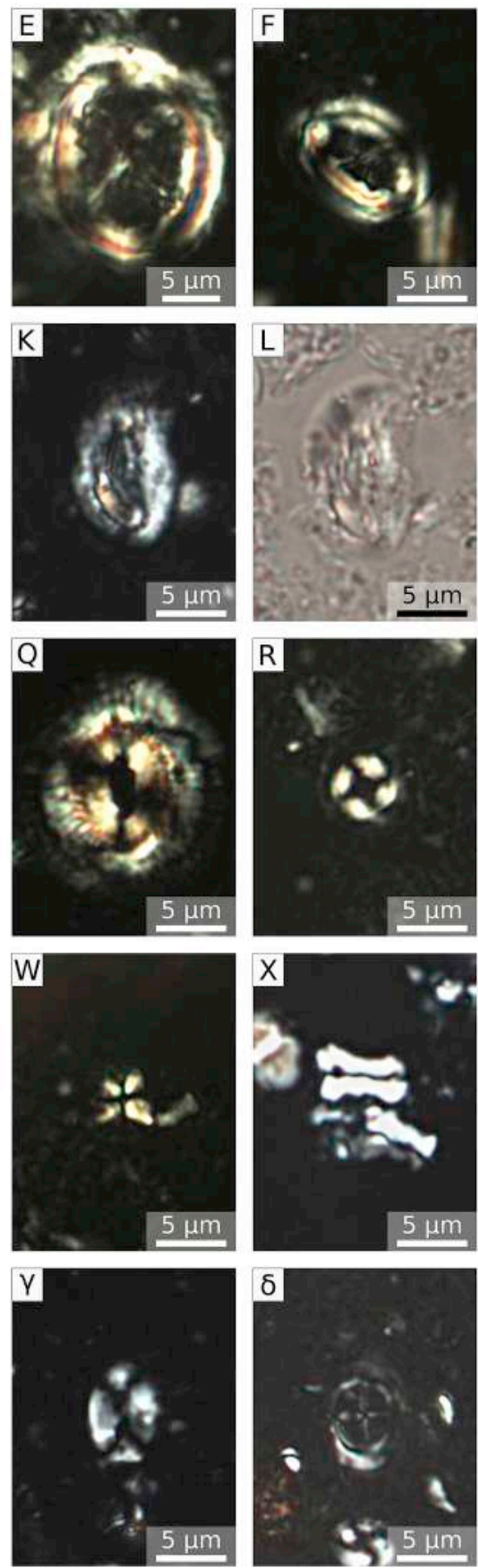

(caption on next page) 


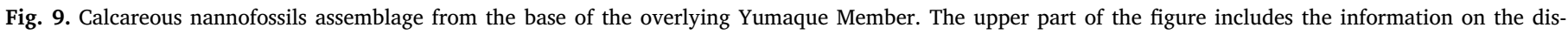

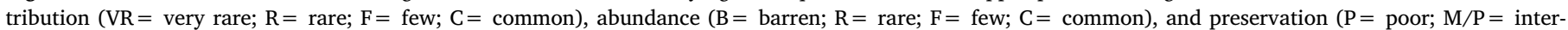

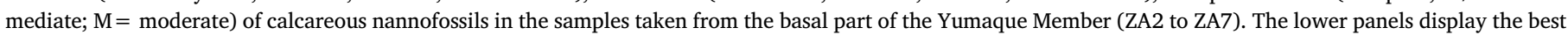

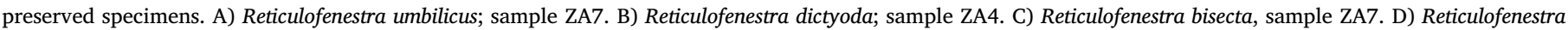

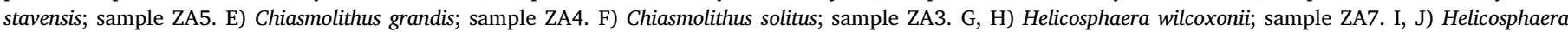

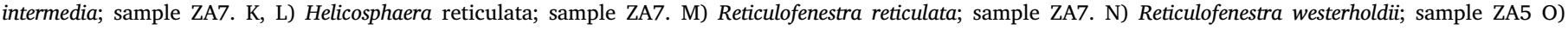

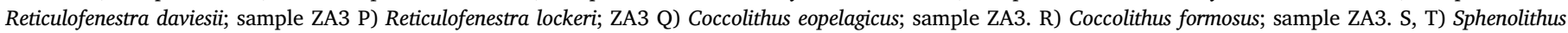

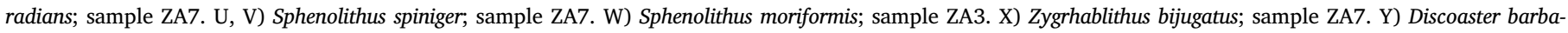

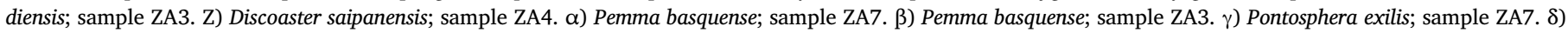
Campylosphaera dela; sample ZA7.

Register of Marine Species (WoRMS; Horton et al., 2019). Crucially, however, this spelling cannot be applied to Lisson's species because it is preoccupied by Lepidocyclina douvillei Prever 1905. In light of the emended International Code of Zoological Nomenclature (ICZN, 1999), Lisson's original spelling of the species name species (i.e., 'R. Douvillei') is regarded as incorrect and must be emended to 'rdouvillei' (article 32.5.2.4.4 of the Code, and related example).

The original description of Lepidocyclina rdouvillei by Lisson (1921) is very detailed. The type material comes from the "Organos Grit" of the middle Eocene Lobitos Formation of the Talara Basin of northern Peru (Todd and Barker, 1932; Higley, 2004). These specimens were described as lens-shaped, 1.5-2 mm in diameter, and devoid of pustules on the outer surface (Lisson, 1921). The embryo is small (PH + DH comprised between 175 and $285 \mu \mathrm{m}$ ) and consists of a protoconch and a deuteroconch of similar size, surrounded by an area of large irregular chamberlets. The regular equatorial chamberlets are arcuate to ogival in shape and they are arranged in a pattern of intersecting curves. This description perfectly matches the morphology of the specimens from the Los Choros Member examined in the present paper.

Lepidocyclina rdouvillei var. armata (whose type material also comes from the Talara Basin) differs from $L$. rdouvillei by the presence of larger pillars (Rutten, 1928). Among the investigated Zamaca specimens, individuals with and without surface pillars occur concurrently. During the thin section preparation, it was observed that these differences were mainly related to the degree of abrasion of the tests. The presence or absence of surface pillars do not appear to correlate with embryonic differences, which are of much greater taxonomic importance for lepidocyclinids (Adams, 1987) and for large benthic foraminifera in general (e.g. Özcan et al., 2019). Furthermore, it has been postulated that, in lepidocyclinids, the presence of pillars could be related to ecophenotypic variations (Ferràndez-Caňadell and Bover-Arnal, 2017). Consequently, we suggest considering $L$. rdouvillei var. armata as a synonym of $L$. rdouvillei. The original description of Lepidocyclina peruviana (Cushman, 1922), whose type material also comes from the Lobitos Formation of northern Peru, lacks any information on the embryo and its characteristics, which frustrates further comparison efforts. However, Todd and Barker (1932) described specimens of L. peruviana coming from the same formation from which the type material of $L$. rdouvillei was collected (i.e. the Lobitos Formation). The description of these individuals matches very well the morphology of the specimens from Zamaca, as well as the description of the type material of $L$. rdouvillei (Lisson, 1921). Todd and Barker (1932) discussed the possibility of L. rdouvillei and L. peruviana being the same species. However, they discarded this hypothesis based on the description of L. rdouvillei provided by Gorter and van der Vlerk (1931) (improperly quoted as "van der Vlerk and Gorter, 1932" in the original paper). The specimens described by Gorter and van der Vlerk (1931) are characterized by a $410-530 \mu \mathrm{m}$ wide embryo, which is significantly different from the type material described by Lisson (1921). In 1933, Todd directly examined the type material of $L$. peruviana and concluded that "All the forms from Mount Organos [ ...] were found to be identical to Lepidocyclina peruviana Cushman" (Todd, 1933). He also revisited the possibility of $L$. peruviana and $L$. rdouvillei being the same species and, although skeptical about the size difference of the embryonic apparatus - a size difference that actually does not exist and derives from using the Gorter and van der Vlerk (1931) description instead of the original description by Lisson (1921) - he concluded that the two forms were synonyms (Todd, 1933). Later, van de Geyn and Van der Vlerk (1935) also came to the conclusion that $L$. peruviana should be considered a synonym of $L$. rdouvillei. Based on the comparison of Lisson's type material with the specimens studied by Todd and Barker (1932), and following van de Geyn and Van der Vlerk (1935), we regard L. peruviana as a junior synonym of $L$. rdouvillei.

It should be noted that the Zamaca specimens ascribed to L. rdouvillei are also similar to Lepidocyclina yurnagunensis, but the latter often presents a deuteroconch slightly embracing the protoconch (e.g., Cushman, 1919). The examined specimens also exhibit some similarities with Lepidocyclina canellei. However, this species is always characterized by equatorial chamberlets arranged in a pattern of concentric rings (e.g., Lemoine and Douvillé, 1904).

\section{Lepidocyclina cf. trinitatis Douvillé (1924) Fig. 11A}

cf. 1924 Lepidocyclina trinitatis Douvillé, pl. 1, Fig. 1, pl. 35, Figs. 7-12.

cf. 1934 Lepidocyclina ariana Cole and Ponton, p. 147, pl. 2, Figs. 1-5.

cf. 1960 Lepidocyclina pustulosa Cole, p. 142, pl. 2, Figs. 3-4.

Material - 3 specimens from sample For1; 1 specimen from sample For8.

Description - Test lenticular, 2-4 $\mathrm{mm}$ in diameter, biconvex, and flattened toward the periphery. External surface characterized by very faint pustules. The embryo of megalospheric specimens consists of a protoconch that is slightly larger than the deuteroconch (PW: 275-315 $\mu \mathrm{m}$, avg. $=300 \mu \mathrm{m}$; DW: $240-265 \mu \mathrm{m}$, avg. $=250 \mu \mathrm{m}$; $\mathrm{PH}+\mathrm{DH}: 370-410 \mu \mathrm{m}$, avg. $=390 \mu \mathrm{m} ; \Delta \mathrm{E}: 23-35 \%$, avg. $=29 \%)$ (Table 1; Fig. 11A). The deuteroconch does not embrace the protoconch (Ai: $16-23 \%$, avg. $=21 \%$ ) and the wall that separates the two chambers is almost straight (Table 1; Fig. 11A). Two slightly asymmetric PACs (QPAC: 1.1-1.8, avg. = 1.4) can be observed on both sides of the embryo (Table 1). Both chambers are large, with their cumulative area being roughly $17 \%$ of the area of the embryo (Table 1; Fig. 11A). The position of the chambers is often asymmetric with respect to the wall that separates the protoconch from the deuteroconch (Fig. 11A). ACIIs were not observed. The embryo is surrounded by an area of irregular chamberlets, slightly different from those placed in the distal part of the equatorial plane. The regular chamberlets of the equatorial plane are arcuate to ogival in shape and are disposed in a pattern of intersecting curves $(\mathrm{F}=1)$.

Remarks - The size and shape of the embryo is similar to the type material of Lepidocyclina trinitatis from Trinidad (first described by 

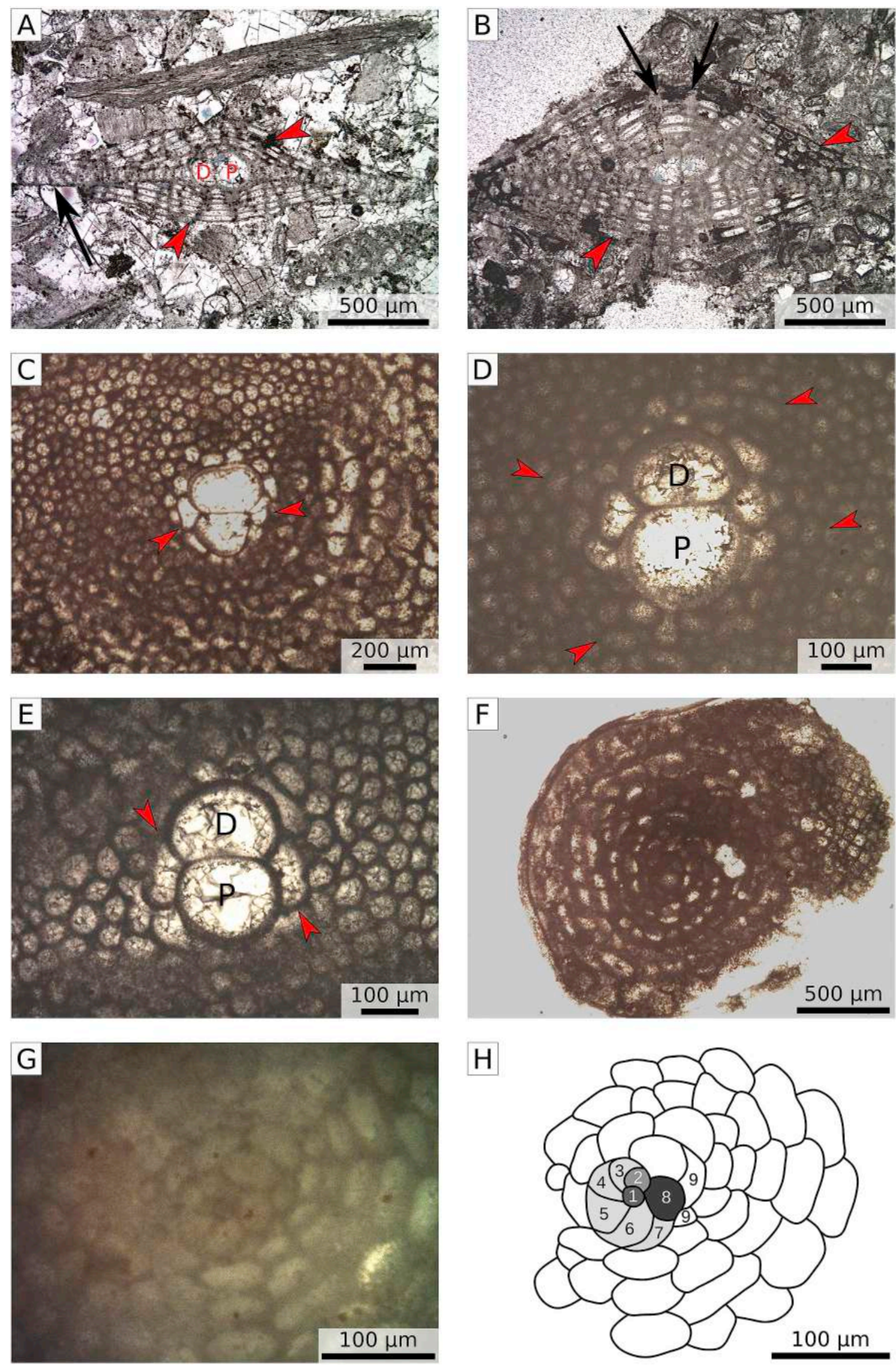

$\mathrm{H}$

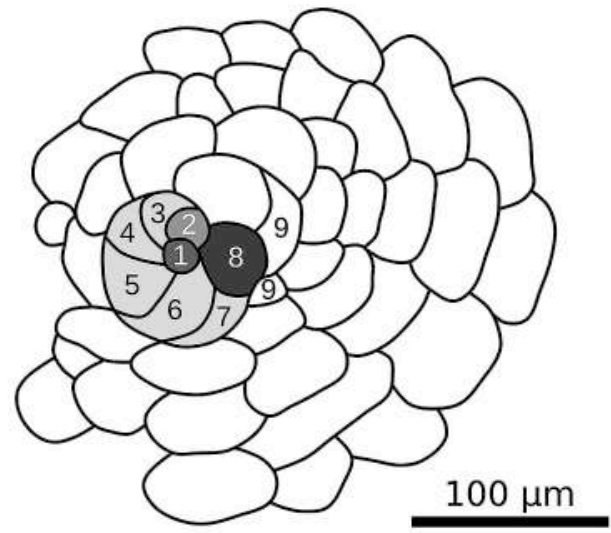




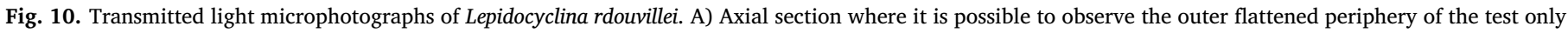

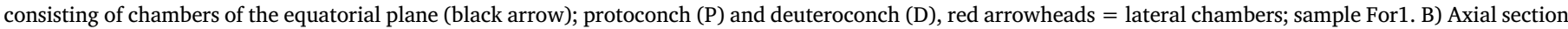

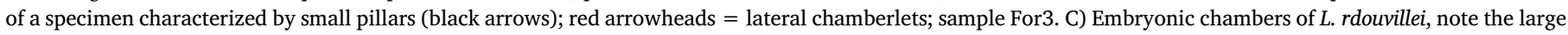

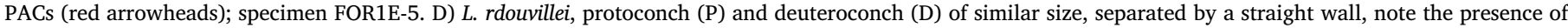

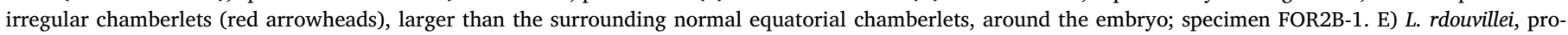

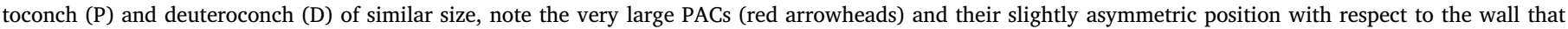

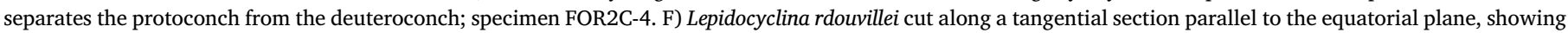

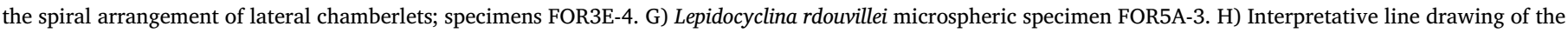

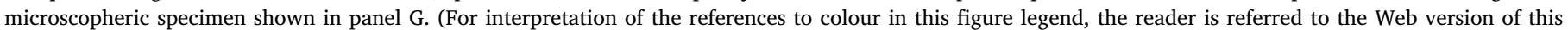
article.)
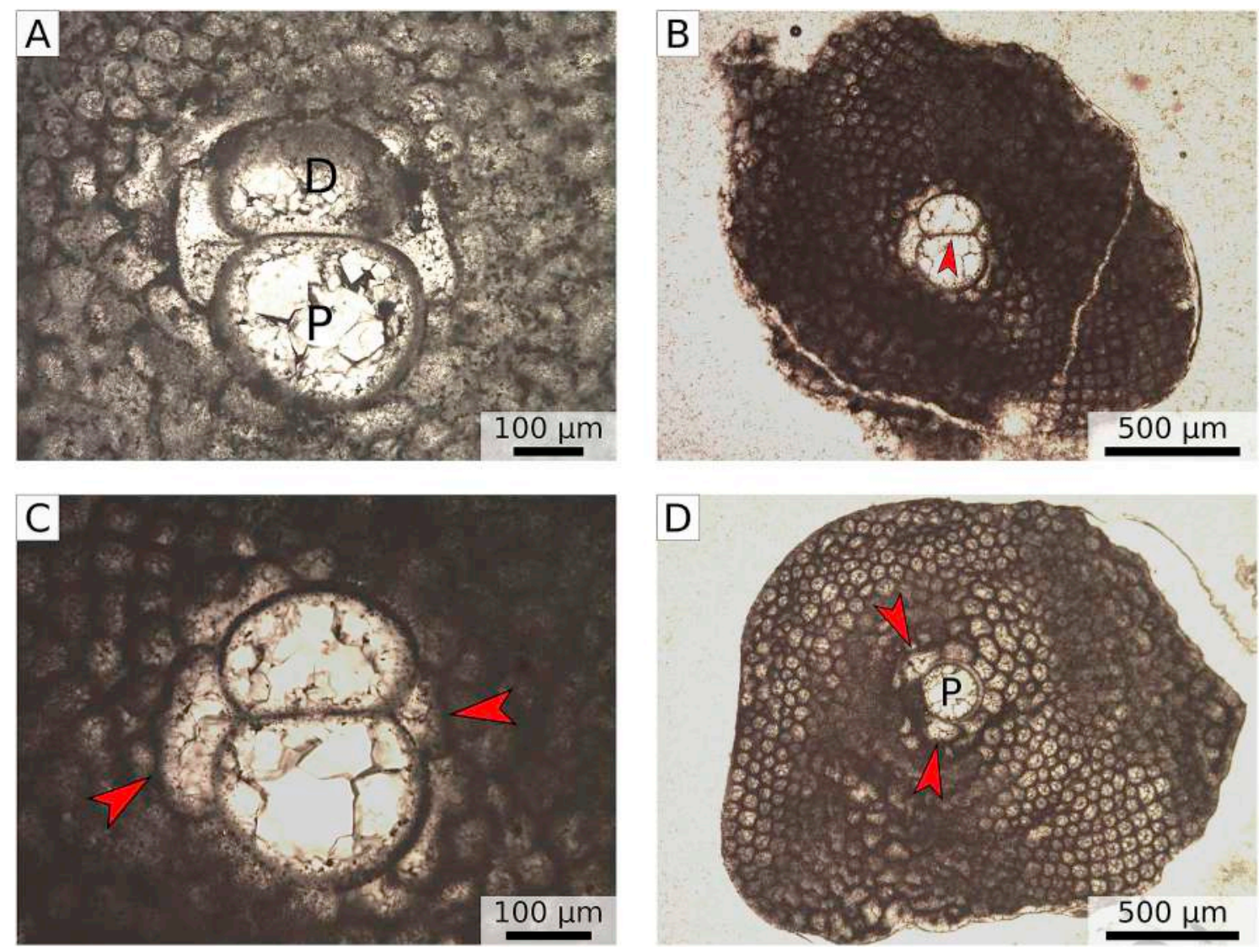

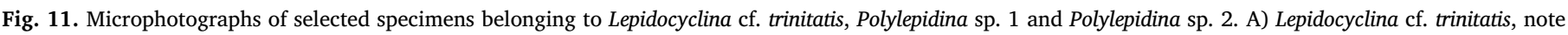

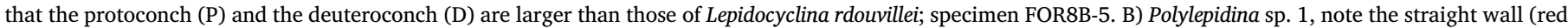

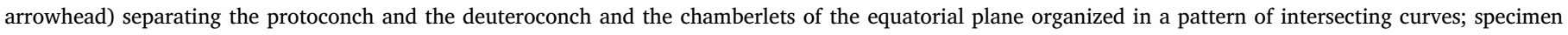

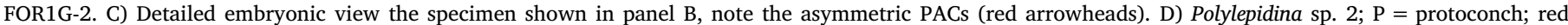

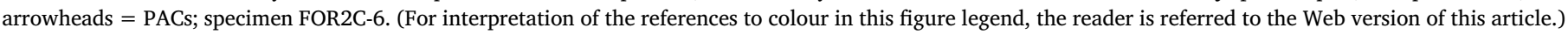

Douvillé in 1917 as Lepidocyclina pustulosa but later recognized as a separate species by the same author in 1924). Similarly to L. rdouvillei, Lepidocyclina cf. trinitatis from the Los Choros beds is characterized by large and often asymmetric PACs. The latter feature is also evident in the original characterization of the type material of $L$. trinitatis (Douvillé, 1924). The Zamaca specimens of $L$. cf. trinitatis are also similar to Lepidocyclina ariana, a species from Florida described by Cole and Ponton (1934). However, the latter exhibits a slightly larger embryo with a protoconch remarkably larger than the deuteroconch. Lepidocyclina ariana is similar to L. trinitatis, and the two species are considered synonyms by some authors (e.g. van de Geyn and Van der Vlerk, 1935). Lepidocyclina cf. trinitatis specimens from Zamaca are also comparable to some lepidocyclinids assigned to the species L. pustulosa (e.g., Cole, 1960). Nevertheless, the type material of $L$. pustulosa, from Trinidad, exhibits a much smaller embryo than the specimens from Zamaca (Douvillé, 1917). According to Vaughan and Cole (1941) L. pustulosa and L. trinitatis are the same species; however, this hypothesis is based only on the external ornamentation and morphology of the two species. As such, until a revision of the type material, focused on the statistical study of the morphology of the embryo and of the periembryonic structures, is undertaken this hypothesis cannot be verified. Lepidocyclina cf. trinitatis of Zamaca can be separated from Lepidocyclina rdouvillei thanks to its significantly larger embryo (Table 1). 

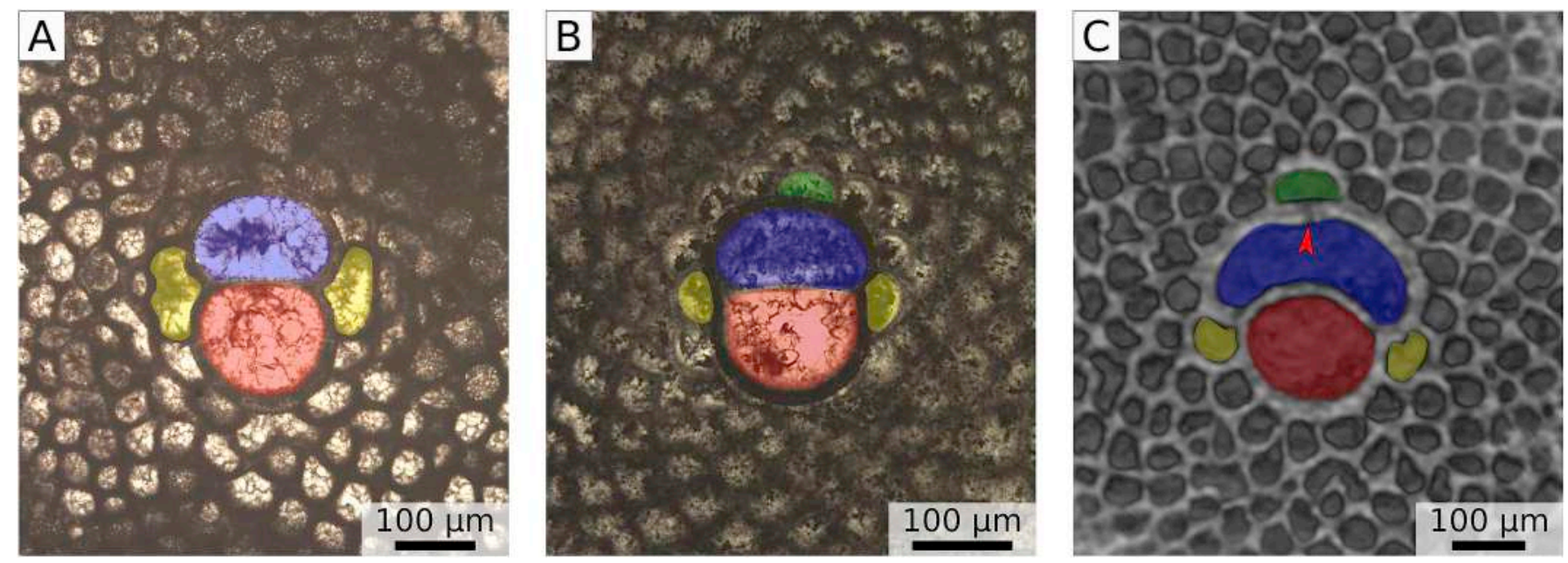

Fig. 12. Comparison between the lepidocyclinids of Zamaca, Cyprus and the Maldives highlighting the different size of the PACs relative to the embryo. Coloured areas denote the different types of embryonic and auxiliary chambers: red = protoconch; blue $=$ deuteroconch; yellow $=$ PACs; green $=$ ACII. A) Lepidocyclina rdouvillei; note the similar protoconch and deuteroconch size, the straight and short wall separating the two, the large PACs, the lack of ACIIs, the irregular chamberlets surrounding the embryo and the more chaotic organization of the equatorial plane; Eocene, Zamaca, specimen FOR3C-6. B) Specimen (CP749G-3) of the analyzed Nephrolepidina ex. interc. praemarginata-morgani population of the Oligocene of Cyprus with characteristics close to Nephrolepidina praemarginata; note the more flattened deuteroconch, the long wall separating the protoconch and deuteroconch, the small PACs, the presence of an ACII and the chamberlets of the equatorial plane organized in a pattern of intersecting curves. C) Specimen (109_6_03) of the analyzed population of Nephrolepidina ex. interc. isolepidinoidessumatrensis of the Oligocene of the Maldives, with characteristics close to Nephrolepidina isolepidinoides; note the deuteroconch slightly embracing the protoconch, the small PACs, the presence of an ACII (red arrowhead = connection between the ACII and the deuteroconch), the chamberlets of the equatorial plane well organized in a pattern of intersecting curves. The image in panel C is different from A and B as it is a virtual section of a 3D model made with CT-scan data. (For interpretation of the references to colour in this figure legend, the reader is referred to the Web version of this article.)

Polylepidina Vaughan, 1924 emend. Adams (1987).bib_Adams_1987

Diagnosis (after Adams, 1987) - Test discoidal, with a distinct layer of equatorial chamberlets and lateral chamberlets on each side. Megalospheric stage with the protoconch larger or slightly larger than the deuteroconch. Embryonic apparatus followed by one PAC or two different sized PACs and surrounded by two to four unequal periembryonic spires. ACIIs do not occur in this genus.

\section{Polylepidina sp. 1 Fig. 11B, C}

Material - 3 specimens from sample For1; 2 specimens from sample For2; 3 specimens from sample For3; 1 specimen from sample For5.

Description - Test lenticular, 2-4 $\mathrm{mm}$ in diameter, biconvex and flattened toward the periphery. The embryo of megalospheric specimens is composed of a protoconch slightly larger than the deuteroconch (PW: 165-310 $\mu \mathrm{m}$, avg. $=230 \mu \mathrm{m}$; DW: $150-260 \mu \mathrm{m}$, avg. $=210 \mu \mathrm{m}$; $\mathrm{PH}+$ DH: $240-401 \mu \mathrm{m}$, avg. $310 \mu \mathrm{m} ; \Delta \mathrm{E}: 5-47 \%$, avg. $=20 \%$ ) (Table 1; Fig. 11B and C). The deuteroconch does not embrace the protoconch and the wall that separates these two chambers is nearly straight (Fig. 11B). Two strongly unequal PACs (QPAC: 0.5-4.8, avg. $=3.2$ ) are present (Fig. $11 \mathrm{C}$ ). ACIIs were not observed. Unequal periembryonic spires surround the embryo; the periembryonic spires are further surrounded by an area of slightly irregular chamberlets. The regular chamberlets of the equatorial plane are arcuate to ogival in shape and are disposed in a pattern of intersecting curves $(F=1)$ (Fig. 11B).

Remarks - Since this species exhibits two unequal PACs, it resembles in this aspect some specimens of Polylepidina variabilis (Rutten, 1928: pl. 1, Fig. 14), Polylepidina chiapasensis (Adams, 1987: pl. 1, Figs. 24-25) and Polylepidina antillea (Eva, 1980: pl. 1, Figs. 3-4). Aside from this similarity, in $P$. chiapasensis and $P$. antillea, the initial chambers of the main nepionic spire, that starts from the largest PAC, are almost as large as the PAC itself (Eva, 1980: pl. 1, Figs. 1, 2, 5-7; Adams, 1987: pl. 1, Figs. 24-25), whereas in Polylepidina sp. 1 they are smaller than the largest PAC (Fig. 11C). From this point of view, Polylepidina sp. 1 is very close to some specimens of Polylepidina variabilis described by Rutten (1928: pl. 1, Fig. 14) from northern Peru. However, there is remarkable variability among the specimens described by Rutten (1928: pl. 1, Figs. 13, 15) and, as such, it is impossible to further discuss the similarities between these two species without a re-examination of Rutten's original material.

\section{Polylepidina sp. 2 Fig. 11D}

Material - 1 specimen from sample For2.

Description - Test lenticular, around $2 \mathrm{~mm}$ in diameter, biconvex and flattened toward the periphery. The embryo of megalospheric specimens is composed of a protoconch much larger than the deuteroconch $(\mathrm{PW}=200 \mu \mathrm{m} ; \mathrm{PH}=190 \mu \mathrm{m} ; \mathrm{DW}=135 \mu \mathrm{m} ; \mathrm{DH}=50)$ (Fig. 11D). Two unequal PACs are observed (Fig. 11D). At least two periembryonic spires surround the embryo (Fig. 11D). Close to the embryo, it is possible to observe a rather large area characterized by irregular chamberlets, generally larger than those that occur at the periphery on the equatorial plane (Fig. 11D). The regular chamberlets of the equatorial plane are arcuate to ogival in shape and are arranged in a pattern of intersecting curves (Fig. 11D).

Remarks - A single specimen of this taxa was observed at Zamaca. It clearly differs from Polylepidina sp. 1 by having a protoconch much larger than the deuteroconch. Although the latter is not perfectly preserved, its size is roughly equal to the size of the PACs. 


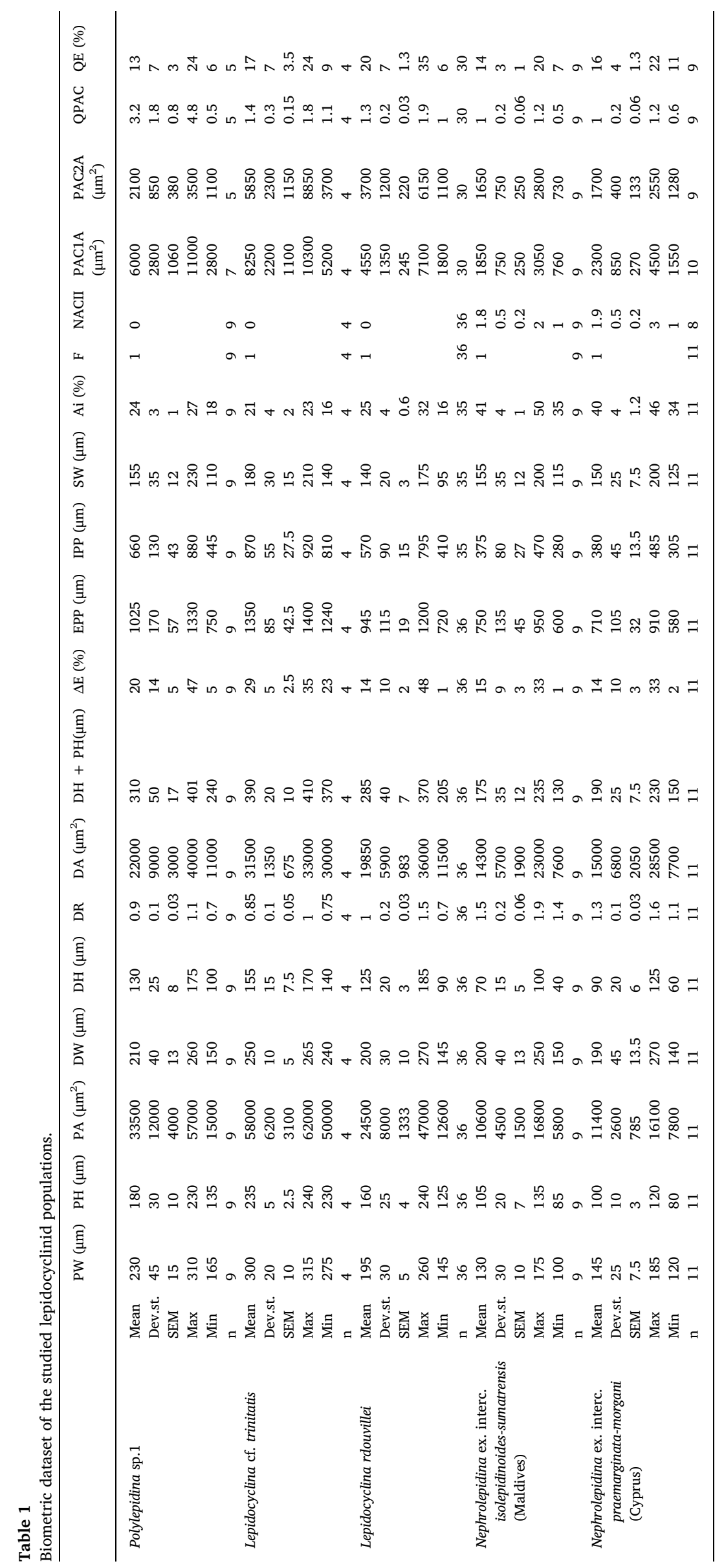


Agnini et al. 2014

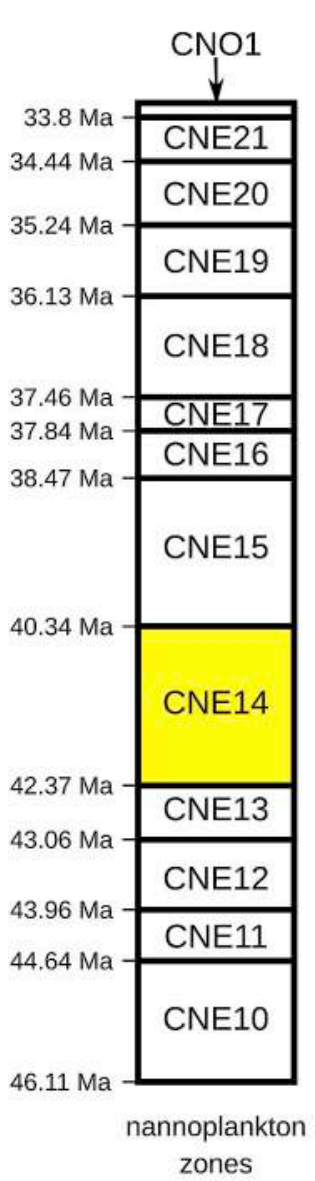

Wade et al. 2011

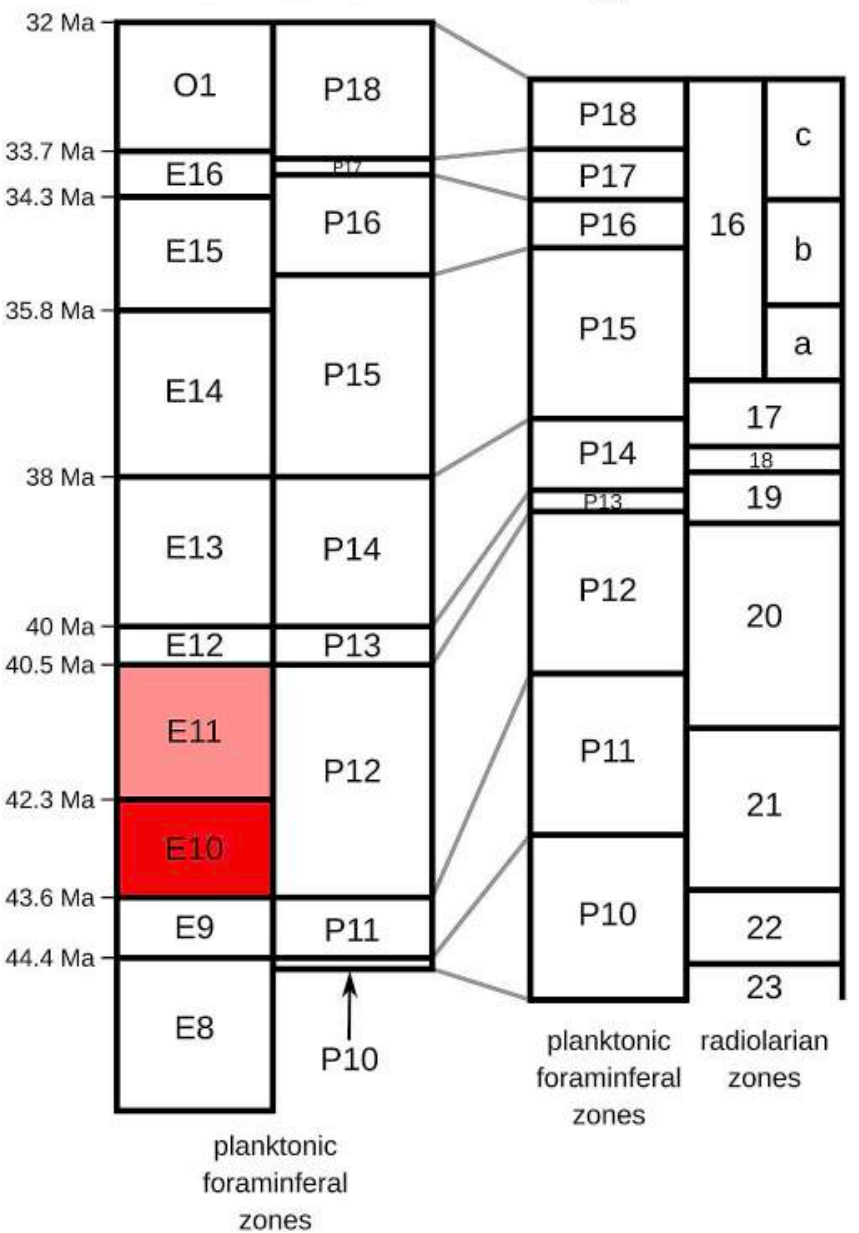

Berggren et al. 1985 the right the correlation between Riedel and Sanfilippo (1978) radiolarian zones and the standard planktonic foraminiferal zones, modified from Berggren et al. (1985); in the center correlation between standard planktonic foraminiferal zones and the calibrated planktonic foraminiferal zones of Wade et al. (2011); On the left nannoplankton zones from Agnini et al., (2014); the light-red interval indicates the age range estimated on the basis of the lepidocyclinid assemblage; the deep-red interval indicates the age range estimated on the basis of lepidocyclinid assemblage and calcareous nannofossils; the yellow interval indicates the extent of zone CNE14 of Agnini et al., (2014). (For interpretation of the references to colour in this figure legend, the reader is referred to the Web version of this article.)

\subsection{Oligocene lepidocyclinid populations from the Maldives and Cyprus}

The Maldivian lepidocyclinid population presents a small embryo (PW: 100-175 $\mu \mathrm{m}$, avg. = $130 \mu \mathrm{m}$; DW: $150-250 \mu \mathrm{m}$, avg. $=200 \mu \mathrm{m}$; PH + DH: $130-235 \mu \mathrm{m}$, avg. $=175 \mu \mathrm{m}$ ), a protoconch only slightly enclosed by the deuteroconch (Ai: 35-50\%, avg. = 41\%) and on average two ACIIs (Table 1 ). Therefore, they are here identified as Nephrolepidina ex. interc. isolepidinoides - sumatrensis, in agreement with Coletti et al. (2018a). Compared to the Zamaca specimens, they display ACIIs, a significantly higher Ai and smaller PACs (QE: 7-20\%, avg. $=14 \%)($ Table 1$)$. They are associated with Heterostegina (Vlerkina) borneensis, Heterostegina (Vlerkina) sp. 1, Cycloclypeus eidae, Amphistegina mammilla, Eulepidina, Operculina and Sphaerogypsina, suggesting a Chattian age (Coletti et al., 2018a).

The lepidocyclinid population of Cyprus is characterized by a small embryo (PW: 120-185 $\mu \mathrm{m}$, avg. = $145 \mu \mathrm{m}$; DW: 140-270 $\mu \mathrm{m}$, avg. $=190 \mu \mathrm{m} ; \mathrm{PH}+\mathrm{DH}: 150-230 \mu \mathrm{m}$, avg. $=190 \mu \mathrm{m})$, with a protoconch only slightly enclosed by the deuteroconch (Ai: 34-36\%, avg. $=40 \%$ ) and, on average two ACIIs (Table 1 ). These parameters fall near the boundary between Nephrolepidina praemarginata and $\mathrm{Ne}$ phrolepidina morgani (Matteucci and Schiavinotto, 1977; Özcan et al., 2009). Consequently, they are identified as Nephrolepidina ex. interc. praemarginata - morgani. Compared to the Zamaca specimens they have ACIIs and a significantly higher Ai. Furthermore, the PACs are smaller, with a cumulative area of around $16 \%$ of the area of the embryo (QE: $11-22 \%$, avg. $=16 \%$ ) (Table 1$)$. They are associated with Eulepidina formosoides, Heterostegina (Vlerkina), Nummulites, Operculina and Amphistegina, suggesting a placement in the Shallow Benthic Zone 22B of
Cahuzac and Poignant (1997), corresponding to the early Chattian Zone O5 of Wade et al. (2011).

\section{Discussion}

6.1. The position of Lepidocyclina rdouvillei and Polylepidina sp. 1 within the American lepidocyclinid lineages

The specimens of Lepidocyclina rdouvillei from Zamaca display very primitive characters that place them close to the archaic spirally-arranged lepidocyclinids. The protoconch and deuteroconch have roughly the same size and the wall that separates them is almost straight, resulting in a very low Ai (Table 1; Fig. 12A). This character is often so pronounced that it is very difficult to identify the deuteroconch, an observation that highlights the importance of using the $\mathrm{PH}+\mathrm{DH}$ parameter for the description of primitive lepidocyclinids. Furthermore, the Zamaca specimens do not possess ACIIs (Fig. 12A). Additionally, the embryo is surrounded by an area of irregular equatorial chamberlets indicating a poor and primitive organization of the equatorial plane (Fig. 12A).

By comparing the Zamaca specimens with the more evolved populations from Cyprus and the Maldives, it is possible to observe another distinctive characteristic: the PACs of $L$. rdouvillei are much larger than those of the more advanced Oligocene species (Table 1; Fig. 12). In particular, the QE ratio is significantly higher in the Peruvian assemblage (Table 1). For interpreting this observation, it must be noted that PACs are modified versions of the third chamber. In spirally-arranged lepidocyclinids the third chamber is generally just as large as the 
deuteroconch and only slightly smaller than the protoconch (e.g. Adams, 1987: text-Fig. 3; Robinson, 1996: fig. a, b, c). Since evolution in lepidocyclinids pushed towards a cyclical organization (i.e. radial symmetric growth), the most primitive species should exhibit large and slightly asymmetric PACs, whereas more evolved species should exhibit PACs almost indistinguishable from the equatorial chamberlets (Table 1; Fig. 12; see also Coletti et al., 2018a: f, h-m). The difference in PAC morphology between $L$. rdouvillei and the more advanced lepidocyclinids from the Oligocene of the Tethys (Fig. 12A and B) suggests that it would be theoretically possible to use the QE ratio for biostratigraphic purposes. However, in order to properly evaluate this ratio, perfectly oriented equatorial sections are necessary - something that requires either a great experience in thin section preparation or material suitable for CT-scan analyses. The spiral pattern of lateral chamberlets observed on tangential sections of $L$. rdouvillei is also most likely a primitive character as it represents a vestige of spiral organization and does not occur in either the Cypriot or Maldivian populations.

Lepidocyclina rdouvillei is also considered a primitive species by Butterlin (1990). This author proposed L. rdouvillei as the first species of a lineage that includes Lepidocyclina pustulosa, Lepidocyclina yurnagunensis, Nephrolepidina tournoueri and Nephrolepidina vaughani (ordered from the oldest to the youngest; Butterlin, 1984, 1990). According to Butterlin (1990), L. rdouvillei evolved from Polylepidina within the Zone P12, corresponding to the zones E11 and E12 (upper Lutetian to lower Bartonian) of Wade et al. (2011).

Polylepidina sp. 1 possesses two asymmetric PACs, four (unequally developed) periembryonic spires and its equatorial layer is almost entirely comprised of cyclically arranged equatorial chamberlets. Since it is possible to apply the principle of Embryonic and Nepionic Acceleration also to spirally-arranged lepidocyclinids of the EulinderinaPolylepidina series (e.g. Robinson, 1996), Polylepidina sp. 1 should be regarded as an extremely advanced representative of its genus as it displays characters that are very close to those of Lepidocyclina.

\subsection{Biostatigraphy}

Lepidocyclina rdouvillei has been reported (as Lepidocyclina peruviana) in the Eocene planktonic foraminferal zones P11 and P12 of the White Limestone Group of Jamaica (Robinson, 2004). These zones correspond to the planktonic foraminferal zones E9 - E11 of Wade et al. (2011), ca. 44.4-40.5 Ma (Fig. 13). Lepidocyclina rdouvillei is also known from the wells of the Foz do Amazonas Basin in the benthic foraminifera zone LF4 of de Mello e Sousa et al. (2003), corresponding to the zones P13 and P14 and to the zones E12 and E13, ca. 40.5-38.0 Ma (Fig. 12). As mentioned above, according to Butterlin (1990), L. rdouvillei evolved from Polylepidina within the zone P12, corresponding to the zones E10 and E11, ca. 43.6-40.5 Ma (Fig. 13). Finally, according to Butterlin (1990) and Robinson $(1997,2004)$, the last occurrence of Polylepidina is located within the zone P13, corresponding to zone E12, ca. 40.5-40 Ma (Fig. 13). Taking into consideration that $L$. rdouvillei is a primitive species of Lepidocyclina and Polylepidina sp. 1 an advanced species of Polylepidina, we propose an age comprised within zones E10 and E11 (i.e., between 43.6 Ma and 40.5 Ma; Fig. 13) for the Los Choros strata of the Paracas Formation exposed in the Zamaca area.

The calcareous nannofossil assemblage from the base of the overlying Yumaque Member (Fig. 9) suggests an age close to the base of biozone CNE14 (ca. 42.37-40.34 Ma; Fig. 13; Agnini et al., 2014). This allows us to restrict the age of the studied Los Choros shallow-marine deposit to an interval comprised between 43.6 and $42.3 \mathrm{Ma}$, corresponding to the late Lutetian (Fig. 13). This age is consistent with the regional stratigraphy. At Media Luna (30 km northwest of Zamaca), the base of the overlying Yumaque Member is dated, using nannofossils and accumulation rates, at $42.8 \mathrm{Ma}$ (Lambert et al., 2017b, 2019). Furthermore, on the basis of radiolarian assemblages, the lower part of the Yumaque Member is placed between 39 and $37 \mathrm{Ma}$ (zone 17, Fig. 13) near Puerto Caballas (30 km southeast of the study area; Dunbar et al.,
1990; Marty, 1989), and between 37 and 34 Ma (zone 16b, Fig. 13) at Fundo Desbarrancado (15 km southeastward of Zamaca; Marty et al., 1988). At Puerto Caballas, the underlaying Caballas Formation has been tentatively attributed by DeVries $(2017,2018)$ to the Ypresian (56-47.8 Ma), based on similarities between the upper Caballas molluskan assemblage and that described by Olsson $(1928,1930)$ from the upper part of the Chacra-Salinas Group of the Talara Basin of northern Peru, which has been placed in the Ypresian by Higley (2004) and Fildani et al. (2008).

Similarly to the East Pisco Basin, Lepidocyclina rdouvillei is also found in the Lobitos and Verdun formations of the Talara Basin in northern Peru, which are confined between the underlying Ypresian Chacra-Salinas Group and the overlying Priabonian Chira Formation (Lisson, 1921; Todd and Barker, 1932; Dunbar et al., 1990; Higley, 2004; Fildani et al., 2008). This piece of evidence further supports the possibility of using lepidocyclinids species for regional-scale correlations in South America.

\subsection{Paleoenvironmental reconstruction and regional implications}

Within the sedimentary infill of the East Pisco Basin it is possible to recognize a series of transgressive cycles (Dunbar et al., 1990; DeVries, 2017; DeVries et al., 2017; Di Celma et al., 2017, 2018a, b). Each cycle presents a coarse-grained lower sediment package, rich in ostreids and barnacles, that relates to the initial phase of the transgression (Dunbar et al., 1990; DeVries, 2017; DeVries et al., 2017; Coletti et al., 2018b, in press; Di Celma et al., 2018a; Collareta et al., 2019). This lower package is overlain by fine-grained sediments, often rich in diatoms, relating to the later phases of the transgression (Dunbar et al., 1990; DeVries, 2017; DeVries et al., 2017; Di Celma et al., 2018a). In the studied section, the Los Choros Member is similar in many aspects to the basal coarse-grained intervals of the other transgressive cycles. Its lower part is rich in barnacles, mollusks and large boulders, and exhibits good sorting and common orientation of the grains, suggesting deposition in a high-energy, coastal environment. The upper part of the section lacks boulders and displays a skeletal assemblage rich in small benthic foraminifera, suggesting a transition toward the Yumaque Member, which represents the late phase of the transgression. However, differently from any other coarse-grained intervals of the East Pisco Basin, the skeletal assemblage of the Los Choros Member is dominated by large benthic foraminifera. Their abundance clearly indicates a tropical climate since their distribution is limited by the $15^{\circ} \mathrm{C}$ winter isotherm (Beavington-Penney and Racey, 2004; BouDagher-Fadel, 2018). This reconstruction contrasts with the cool water setting proposed by Uhen et al. (2011) on the basis of microfossils, like Bolivina, Nonion and Coccolithus pelagicus, that, actually, have broad environmental distributions (e.g. Cachao and Moita, 2000; Murray, 2006). When compared to other Eocene successions of the American bioprovince (e.g., Gorter and van der Vlerk, 1931; Todd and Barker, 1932; Rutten, 1935; Robinson, 2004; de Mello e Sousa et al., 2003; Serra-Kiel et al., 2007; Molina et al., 2016; Cotton et al., 2018), the Zamaca assemblage presents a low species-diversity. Temperature and trophic regime control the diversity of large benthic foraminiferal assemblages, with diversity being highest in very warm oligotrophic environments (BeavingtonPenney and Racey, 2004). The abundance of barnacles in the lower part of the section points towards a moderate nutrient supply during the deposition of the Los Choros Member in the Zamaca area. Barnacles (and, more generally, heterotrophic suspension feeders) thrive in nutrient-rich settings (Hallock and Schlager, 1986; Brasier, 1995; Halfar et al., 2004; Coletti et al., 2017, 2018b). Thus, a reasonable hypothesis is that the Los Choros assemblage developed in a tropical setting characterized by moderate upwelling supplying food for barnacles and slightly decreasing water temperature; a situation similar to the present-day Pacific coast of Panama (e.g., Reijmer et al., 2012). This reconstruction is consistent with late Lutetian oceanographic conditions along the Pacific Coast of Peru, characterized by a weak upwelling 
system driven by a proto-Humboldt current related to the South Pacific Gyre (Marty et al., 1988). A tropical climate during the late Lutetian is also in agreement with the presence of early protocetids in the lowermost portion of the Yumaque Member (Lambert et al., 2019). This group of primitive amphibious cetaceans originated in Asia during the early Eocene (Gingerich et al., 2001) and reached a circum-equatorial distribution by late Eocene times (Lambert et al., 2019). The finding of Peregrinocetus pacificus (Lambert et al., 2019), which constitutes the first indisputable record of a four-legged amphibious whale from the Pacific Ocean and the Southern Hemisphere, further sheds light on the dispersal pattern of these organisms. Sharing features with other protocetids from the Bartonian of Morocco and Nigeria, P. pacificus lends some support to the hypothesis of an initial dispersal pathway across the South Atlantic. During the late Lutetian, the presence (at least between the Caribbean and the Pacific) of a shallow-water passage (suitable for amphibious vertebrates) is in agreement with large benthic foraminifera distribution, as testified by the presence of Lepidocyclina rdouvillei in the late Lutetian deposits of both Jamaica (Robinson, 2004) and southern Peru.

\section{Conclusion}

The large benthic foraminifera-rich deposits of the Los Choros Member at Zamaca are characterized by low diversity assemblages largely dominated by Lepidocyclina rdouvillei. These specimens represent the southernmost occurrence of lepidocyclinids along the Pacific coast of South America. According to the main evolutionary trend of the group, $L$. rdouvillei is a very primitive species. In L. rdouvillei, the protoconch and the deuteroconch have the same size and the wall that separates them is short and straight, an extremely primitive configuration from the point of view of Embryonic Acceleration. Lepidocyclina rdouvillei is also primitive from the point of view of Nepionic Acceleration: the deuteroconch lacks auxiliary chamberlets and the principal auxiliary chambers are very large with respect to the total size of the embryo. When compared to more advanced lepidocyclinid species, the latter character is particularly evident, highlighting the possibility of using the ratio between principal auxiliary chambers and the embryo in lepidocyclinid biostratigraphy. Finally, the large area of irregular equatorial chamberlets that surrounds the embryo indicates a very basal position for $L$. rdouvillei also along the trend of Neanic Acceleration. Based on the known distribution of $L$. rdouvillei and the primitive characteristics of the Zamaca population, we propose a middle Eocene age, comprised between 43.6 Ma and 40.5 Ma, for the Los Choros strata. This is supported by the co-occurrence of a highly evolved species of Polylepidina (i.e. Polylepidina sp. 1). This range is further constrained by nannofossil assemblages that indicate an age close to $42.37 \mathrm{Ma}$ for the base of the overlying Yumaque Member. Lepidocyclina rdouvillei-bearing deposits are also known from the middle Eocene of the Talara Basin of northern Peru, supporting the possibility of using lepidocyclinid species for regional-scale correlations in South America.

The lower part of the Los Choros section is rich in coarse-grained siliciclastic material and presents a skeletal assemblage dominated by large benthic foraminifera, with common barnacles and echinoids, and rare bryozoans and coralline algae (including the first ever reported from the East Pisco Basin). This is suggestive of a shallow-water environment close to the rocky coast of the basin. Towards the top of the section, the material is finer-grained and small benthic foraminifera become more common, suggesting an increase in water-depth. The abundance of large benthic foraminifera in the Los Choros Member is unique in the East Pisco Basin and unequivocally indicates tropical conditions. The low species diversity of the studied lepidocyclinid assemblage, together with the abundance of barnacles, suggests a moderate nutrient supply, probably related to a still weak upwelling system.

These results highlight the potential of large benthic foraminifera for both biostratigraphic and paleoenvironmental reconstructions in the South American region.

\section{Acknowledgments}

The authors would like to thank A. Benedetti for his careful and extensive revision of large benthic foraminifera taxonomy and paleontology, a second anonymous reviewer for his wise suggestions that greatly improved the quality of this work, and Francisco Vega Vera (Universidad Nacional Autónoma de México) for his editorial work and his courtesy. The authors are also grateful to M. Urbina, R. Varas-Malca and W. Aguirre for their assistance in the field. The authors would like to thank G. Molli and G. Sarti for the interesting geological discussions on the area, and R. Cimò for the help in collecting samples. A particular thanks to D. Kroon for the encouraging talks and the useful suggestions on foraminifera and paleoceanography. Special thanks to T. J. DeVries for the interesting discussions on the East Pisco Basin. This study was supported by grants from the Italian Ministero dell'Istruzione dell'Università e della Ricerca (PRIN Project 2012YJSBMK) and by the Università di Pisa (PRA_2017_0032).

\section{Appendix A. Supplementary data}

Supplementary data to this article can be found online at https:// doi.org/10.1016/j.jsames.2019.102372.

\section{References}

Adams, C.G., 1976. Larger foraminifera and the late Cenozoic history of the Mediterranean region. Palaeogeogr. Palaeoclimatol. Palaeoecol. 20, 47-66.

Adams, C.G., 1987. On the classification of the Lepidocyclinidae (foraminifera) with redescription of the unrelated paleocene genera Actinosiphon and Orbitosiphon. Micropaleontology 33, 289-317.

Agnini, C., Fornaciari, E., Raffi, I., Catanzariti, R., Palike, H., Backman, J., Rio, D., 2014. Biozonation and biochronology of Paleogene calcareous nannofossils from low and middle latitudes. Newslett. Stratigr. 47, 131-181.

Baccelle, L., Bosellini, A., 1965. Diagrammi per la stima visiva della composizione percentuale nelle rocce sedimentarie. Annali Università di Ferrara, Nuova Serie, Sezione IX, Scienze Geologiche e Paleontologiche 1, 59-89.

Banner, F.T., Lord, A.R., BouDagher-Fadel, M.K., 1999. The terra Limestone member (Miocene) of western Cyprus. Greifswald. Geowiss. Beitrage 6, 489-501.

Baumgartner-Mora, C., Baumgartner, P.O., 2016. Paleocene earliest Eocene larger benthic foraminifera and Ranikothalia bearing carbonate paleoenvironments of Costa Rica (South Central America). Micropaleontology 62, 453-508.

Beavington-Penney, S.J., Racey, A., 2004. Ecology of extant nummulitids and other large benthic foraminifera in paleoenvironmental analysis. Earth Sci. Rev. 67, 219-265.

Bendetti, A., 2015. Twin embryos in the larger benthic foraminifer Nephrolepidina praemarginata. J. Mediterr. Earth Sci. 7, 9-17.

Benedetti, A., 2014. Spiral growth in Nephrolepidina: evidence of "golden selection". Paleobiology 40, 151-161.

Benedetti, A., Pignatti, J., 2013. Conflicting evolutionary and biostratigraphical trends in Nephrolepidina praemarginata (Douvillé, 1908) (Foraminiferida). Hist. Biol. 25, 363-383.

Berggren, W.A., Kent, D.V., Flynn, J.J., Van Couvering, J.A., 1985. Cenozoic geochronology. Geol. Soc. Am. Bull. 96 (11), 1407-1418.

Betzler, C., Eberli, G.P., Alvarez Zarikian, C.A., Alonso-García, M., Bialik, O.M., Blättler, C.L., Guo, J.A., Haffen, S., Horozal, S., Inoue, M., Jovane, L., Kroon, D., Lanci, L., Laya, J.C., Ling Hui Mee, A., Lüdmann, T., Nakakuni, M., Nath, B.N., Niino, K., Petruny, L.M., Pratiwi, S.D., Reijmer, J., Reolid, J., Slagle, A.L., Sloss, C.R., Su, X., Swart, P.K., Wright, J.D., Yao, Z., Young, J.R., 2017. Site U1468. In: In: Betzler, C., Eberli, G.P., Alvarez Zarikian, C.A., the Expedition 359 Scientists (Eds.), Maldives Monsoon and Sea Level. Proceedings of the International Ocean Discovery Program International Ocean Discovery Program, College Station, TX, pp. 1-40.

Bianucci, G., Urbina, M., Lambert, O., 2015. A new record of Notocetus vanbenedeni (Squalodelphinidae, Odontoceti, Cetacea) from the early Miocene of Peru. Comptes Rendus Palevol 14, 5-13.

Bianucci, G., Di Celma, C., Collareta, A., Landini, W., Post, K., Tinelli, C., de Muizon, C., Bosio, G., Gariboldi, K., Gioncada, A., Malinverno, E., Cantalamessa, G., AltamiranoSierra, A., Salas-Gismondi, R., Urbina, M., Lambert, O., 2016a. Fossil marine vertebrates of Cerro Los Quesos: distribution of cetaceans, seals, crocodiles, seabirds, sharks, and bony fish in a late Miocene locality of the Pisco Basin, Peru. J. Maps 12, 1037-1046.

Bianucci, G., Di Celma, C., Landini, W., Post, K., Tinelli, C., de Muizon, C., Gariboldi, K., Malinverno, E., Cantalamessa, G., Gioncada, A., Collareta, A., Salas-Gismondi, R., Varas-Malca, R.M., Urbina, M., Lambert, O., 2016b. Distribution of fossil marine vertebrates in Cerro Colorado, the type locality of the giant raptorial sperm whale Livyatan melvillei (Miocene, Pisco Formation, Peru). J. Maps 12, 543-557.

Bianucci, G., Collareta, A., Bosio, G., Landini, W., Gariboldi, K., Gioncada, A., Lambert, O., Malinverno, E., de Muizon, C., Varas-Malca, R., Villa, I.M., Coletti, G., Urbina, M., Di Celma, C., 2018. Taphonomy and palaeoecology of the lower Miocene marine vertebrate assemblage of ullujaya (chilcatay formation, East Pisco basin, southern 
Peru). Palaeogeogr. Palaeoclimatol. Palaeoecol. 511, 256-279.

BouDagher-Fadel, M.K., 2018. Evolution and Geological Significance of Larger Benthic Foraminifera. University College London Press, London.

BouDagher-Fadel, M.K., Price, G.D., 2010. Evolution and paleogeographic distribution of the lepidocyclinids. J. Foraminifer. Res. 40, 79-108.

Bown, P.R., 1998. Calcareous Nannofossil Biostratigraphy. Kluwer Academic, London.

Bown, P.R., Young, J.R., 1998. Techniques. In: Bown, P.R. (Ed.), Calcareous Nannofossil Biostratigraphy. Kluwer Academic, London, pp. 16-28.

Brasier, M.D., 1995. Fossil indicators of nutrient levels 1: eutrophication and climate change. In: In: Bosence, D.W.J., Allison, P.A. (Eds.), Marine Paleoenvironmental Analysis from Fossils, vol. 83. Geological Society Special Publication, pp. 113-132.

Briguglio, A., 2018. The Miocene (burdigalian) lepidocyclinids and miogypsinids of Channa Kodi, Padappakkara, Kerala, Southern India. Palaeontogr. Abt A: Palaeozool. - Stratigr. 312, 1-15.

Butterlin, J., 1984. Notes on some larger foraminifera from the Tertiary of the French Lesser Antilles and on the phylogeny of American species of the genus Lepidocyclina. Bull. Cent. Rech. Explor.-Prod. Elf-Aquitaine - Mem. 6, 105-115.

Butterlin, J., 1990. Problèmes poses par la systématique de la famille Lepidocyclinidae (Foraminiferida). Rev. Espanola Micropaleontol. 22, 101-126.

Cachao, M., Moita, M.T., 2000. Coccolithus pelagicus, a productivity proxy related to moderate fronts off Western Iberia. Mar. Micropaleontol. 39, 131-155.

Cahuzac, B., Poignant, A., 1997. Essai de biozonation de l'Oligo-Miocène dans le bassins européens à l'aide des grands foraminifères néritique. Bull. Soc. Geol. Fr. 168, 155-169.

Chaproniere, G.C.H., 1980. Biometrical studies of early Neogene larger Foraminiferida from Australia and New Zealand. Alcheringa 4, 153-181.

Clarke, J.A., Ksepka, D.T., Stucchi, M., Urbina, M., Giannini, N., Bertelli, S., Narváez, Y., Boyd, C.A., 2007. Paleogene equatorial penguins challenge the proposed relationship between biogeography, diversity, and Cenozoic climate change. Proc. Natl. Acad. Sci. 104, 11545-11550.

Clarke, J.A., Ksepka, D.T., Salas-Gismondi, R., Altamirano, A.J., Shawkey, M.D., D'Alba, L., Vinther, J., DeVries, T.J., Baby, P., 2010. Fossil evidence for evolution of the shape and color of penguin feathers. Science 330, 954-957.

Cole, W.S., 1960. Variability in embryonic chambers of Lepidocyclina. Micropaleontology 6, 133-144.

Cole, W.S., Ponton, G.M., 1934. New species of Fabularia, Asterocyclina and Lepidocyclina from the Florida Eocene. Am. Midl. Nat. 15, 138-147.

Coletti, G., Collareta, A., Bosio, G., Urbina-Schmitt, M., Buckeridge, J., (in press). Perumegabalanus calziai gen. et sp. nov., a new intertidal megabalanine barnacle from the early Miocene of Peru. Neues Jahrb. Geol. Palaontol. Abh.

Coletti, G., El Kateb, A., Basso, D., Cavallo, A., Spezzaferri, S., 2017. Nutrient influence on fossil carbonate factories: evidence from SEDEX extractions on Burdigalian limestones (Miocene, NW Italy and S France). Palaeogeogr. Palaeoclimatol. Palaeoecol. 475, 80-92.

Coletti, G., Stainbank, S., Fabbrini, A., Spezzaferri, S., Foubert, A., Kroon, D., Betzler, C., 2018a. Biostratigraphy of large benthic foraminifera from Hole U1468A (Maldives): a CT-scan taxonomic approach. Swiss J. Geosci. 111, 523-536.

Coletti, G., Bosio, G., Collareta, A., Buckeridge, J., Consani, S., El Kateb, A., 2018b. Palaeoenvironmental analysis of the Miocene barnacle facies: case studies from Europe and South America. Geol. Carpathica 69, 573-592.

Collareta, A., Coletti, G., Bosio, G., Buckeridge, J., de Muizon, C., DeVries, T.J., VarasMalca, R., Altamirano-Sierra, A., Urbina-Schmitt, M., Bianucci, G., 2019. A new barnacle (Cirripedia: Neobalanoformes) from the early Miocene of Peru: palaeoecological and palaeobiogeographical implications. Neues Jahrb. Geol. Palaontol. Abh. 292, 321-338.

Cotton, L., Eder, W., Floyd, J., 2018. Larger foraminifera of the Devil's Den and Blue Holes sinkholes, Florida. J. Micropalaeontol. 37, 347-356.

Cushman, J.A., 1919. Fossil foraminifera from the west indies. In: In: Vaughan, T.V. (Ed.), Contribution to the Geology and Paleontology of the West Indies, vol. 291. Carnegie Institute of Washington Publication, pp. 21-73.

Cushman, J.A., 1922. Foraminifera from the Eocene deposits of Peru. In: Bosworth, T.O. (Ed.), Geology of the Tertiary and Quaternary Periods in the North-West Part of Peru. Macmillan and Company, London, pp. 51-142.

de Mello e Sousa, S.H., Fairchild, T.R., Tibana, P., 2003. Cenozoic biostratigraphy of larger foraminifera from the Foz do Amazonas Basin, brasil. Micropaleontology 49, 253-266.

DeVries, T.J., 1998. Oligocene deposition and cenozoic sequence boundaries in the Pisco Basin (Peru). J. South Am. Earth Sci. 11, 217-231.

DeVries, T.J., 2017. Eocene stratigraphy and depositional history near Puerto Caballas (East Pisco basin, Peru). Bol. Soc. Geol. Peru 112, 39-52.

DeVries, T.J., 2018. Early Paleogene brackish-water molluscs from the Caballas Formation of the East Pisco Basin (southern Peru). J. Nat. Hist. https://doi.org/10 1080/00222933.2018.1524032.

DeVries, T.J., Jud, N.A., 2018. Lithofacies patterns and paleogeography of the Miocene chilcatay and lower Pisco depositional sequences (East Pisco basin, Peru). Bol. Soc. Geol. Peru 8, 124-167.

DeVries, T.J., Groves, L.T., Urbina, M., 2006. A new early Miocene muracypraea Woodring, 1957 (Gastropoda: Cypraeidae) from the Pisco Basin of southern Peru. Nautilus 120, 101-105.

DeVries, T.J., Urbina, M., Jud, N.A., 2017. The Eocene-Oligocene Otuma depositional sequence (East Pisco Basin, Peru): paleogeographic and paleoceanographic implications of new data. Bol. Soc. Geol. Peru 112, 14-38.

Di Celma, C., Malinverno, E., Bosio, G., Collareta, A., Gariboldi, K., Gioncada, A., Molli, G., Basso, D., Varas-Malca, R.M., Pierantoni, P.P., Villa, I.M., Lambert, O., Landini, W., Sarti, G., Cantalamessa, G., Urbina, M., Bianucci, G., 2017. Sequence stratigraphy and paleontology of the upper Miocene Pisco Formation along the western side of the lower Ica valley (Ica Desert, Peru). Riv. Ital. Paleontol. Stratigr. 123, 255-274.

Di Celma, C., Malinverno, E., Collareta, A., Bosio, G., Gariboldi, K., Lambert, O., Landini, W., Gioncada, A., Villa, I.M., Coletti, G., de Muizon, C., Urbina, M., Bianucci, G., 2018a. Facies analysis, stratigraphy and marine vertebrate assemblage of the early Miocene Chilcatay Formation at Ullujaya (Pisco basin, Peru). J. Maps 14, 257-268.

Di Celma, C., Malinverno, E., Bosio, G., Gariboldi, K., Collareta, A., Gioncada, A., Landini, W., Pierantoni, P.P., Bianucci, G., 2018b. Intraformational unconformities as a record of late Miocene eustatic falls of sea level in the Pisco Formation (southern Peru). J. Maps 14, 607-619.

Di Celma, C., Pierantoni, P.P., Malinverno, E., Collareta, A., Lambert, O., Landini, W., Bosio, G., Gariboldi, K., Gioncada, A., de Muizon, C., Molli, G., Marx, F.G., VarasMalca, R.M., Urbina, M., Bianucci, G., 2019. Allostratigraphy and paleontology of the lower Miocene chilcatay formation in the Zamaca area, East Pisco basin, southern Peru. J. Maps 15, 393-405.

Douvillé, H., 1917. Les Orbitoides de l'île de la Trinité, deuxième note. Comptes Rendus de l'Académie de Sciences 164, 841-847.

Douvillé, H., 1924. Les Orbitoides et leur évolution en Amerique. Bull. Soc. Geol. Fr. 23, 369-376. Consulted through Ellis \& Messina Catalogue, accessed February 2019. http://www.micropress.org/em/about.php.

Doyle, P., Mather, A.E., Bennet, M.R., Bussel, M.A., 1997. Miocene barnacle assemblages from Southern Spain and their palaeoenvironmental significance. Lethaia 29, 267-274.

Drooger, C.W., 1984. Evolutionary patterns in lineages of orbitoidal foraminifera. Proc. Koninklke Nederlandse Akademie van Wetenschappen. Series B. Palaeontol., Geol., Phys. Chem. 87, 103-130.

Drooger, C.W., 1993. Radial foraminifera; morphometrics and evolution. Proc. R. Acad, Sci. Arts Neth., Sci. Ser. 41, 1-242.

Drooger, C.W., Socin, C., 1959. Miocene foraminifera from Rosignano, northern Italy. Micropaleontology 5, 415-426.

Dunbar, R.B., Marty, R.C., Baker, P.A., 1990. Cenozoic marine sedimentation in the Sechura and Pisco basins, Peru. Palaeogeogr. Palaeoclimatol. Palaeoecol. 77, 235-261.

Eva, A.N., 1980. Pre-cyclical chamber arrangement in the foraminiferal genus Polylepidina Vaughan, 1924. Micropaleontology 26, 90-94.

Ferràndez-Caňadell, C., Bover-Arnal, T., 2017. Late Chattian larger foraminifera from the Prebetic domain (SE Spain): new data on shallow benthic zone 23. Palaios 32, 83-109.

Fildani, A., Hessler, A.M., Graham, S.A., 2008. Trench-forearc interactions reflected in the sedimentary fill of the Talara basin, northwest Peru. Basin Res. 20, 305-331.

Flügel, E., 2010. Microfacies of Carbonate Rocks: Analysis Interpretation and Application. Springer, New York.

Gingerich, P.D., Haq, M.U., Zalmout, I.S., Khan, I.H., Sadiq-Malkani, M., 2001. Origin of whales from early artiodactyls: hands and feet of Eocene Protocetidae from Pakistan. Science 293, 2239-2242.

Gioncada, A., Gariboldi, K., Collareta, A., Di Celma, C., Bosio, G., Malinverno, E., Lambert, O., Pike, J., Urbina, M., Bianucci, G., 2018a. Looking for the key to preservation of fossil marine vertebrates in the Pisco Formation of Peru: new insight from a small dolphin skeleton. Andean Geol. 45, 379-398.

Gioncada, A., Petrini, R., Bosio, G., Gariboldi, K., Collareta, A., Malinverno, E., Bonaccorsi, E., Di Celma, C., Pasero, M., Urbina, M., Bianucci, G., 2018b. Insights into the diagenetic environment of fossil marine vertebrates of the Pisco Formation (late Miocene, Peru) from mineralogical and Sr-isotope data. J. South Am. Earth Sci. 81, $141-152$.

Gorter, N.E., van der Vlerk, I.M., 1931. Larger foraminifera from central falcon (Venezuela). Leidse Geol. Meded. 4, 94-122.

Gümbel, C.W., 1870. Beiträge zur Foraminiferenfauna der Nordalpine Eocängelibe. Abhandlungen der Mathematisch-Physikalischen Classe der Königlich Bayerischen Akademie der Wissenschaften 10, 581-730.

Halfar, J., Godinez-Orta, L., Mutti, M., Valdez-Holguìn, J.E., Borges, J.M., 2004. Nutrient and temperature controls on modern carbonate production: an example from the Gulf of California. Mexico. Geology 32, 213-216.

Hallock, P., Schlager, W., 1986. Nutrient excess and the demise of coral reefs and carbonate platforms. Palaios 1, 389-398.

Hallock, P., Sheps, K., Chaproniere, G., Howell, M., 2006. Larger benthic foraminifera of the Marion Plateau, Northeastern Australia (ODP Leg 194): comparison of faunas from bryozoans (Sites 1193 and 1194) and red algal (Sites 1196-1198) dominated carbonate platforms. In: In: Anselmetti, F.S., Blum, P., Betzler, C. (Eds.), Proceedings of the Ocean Drilling Program, vol. 194. Scientific Results, pp. 1-31.

Hampel, A., 2002. The migration history of the Nazca Ridge along the Peruvian active margin: a re-evaluation. Earth Planet. Sci. Lett. 203, 665-679.

Higley, D.K., 2004. The Talara Basin province of northwestern Peru. Cretaceous-Tertiary Total Petroleum System. US Department of the Interior, US Geological Survey.

Hohenegger, J., 2011. Growth-invariant meristic characters tools to reveal phylogenetic relationships in Nummulitidae (Foraminifera). Turk. J. Earth Sci. 20, 655-681.

Horton, T., et al., 2019. World register of marine species. Available from: 2019-05-08. http://www.marinespecies.org at VLIZ.

ICZN [International Commission on Zoological Nomenclature], 1999. International Code of Zoological Nomenclature, fourth ed. International Trust for Zoological Nomenclature, London.

Hottinger, L., 2006. Illustrated Glossary of Terms Used in Foraminiferal Research. Notebooks on Geology Memoir 2.

Lambert, O., Bianucci, G., Urbina, M., 2014. Huaridelphis raimondii, a new early Miocene squalodelphinidae (cetacea, odontoceti) from the Chilcatay Formation, Peru. J. Vertebr. Paleontol. 34, 987-1004.

Lambert, O., de Muizon, C., Bianucci, G., 2015. A new archaic homodont toothed cetacean (Mammalia, Cetacea, Odontoceti) from the early Miocene of Peru. Geodiversitas 
37, 79-108.

Lambert, O., Bianucci, G., Urbina, M., Geisler, J.H., 2017a. A new inioid (Cetacea, Odontoceti, Delphinidae) from the Miocene of Peru and the origin of modern dolphin and porpoise families. Zool. J. Linn. Soc. 179, 919-946.

Lambert, O., Martínez-Cáceres, M., Bianucci, G., Di Celma, C., Salas-Gismondi, R., Steurbaut, E., Urbina, M., de Muizon, C., 2017b. Earliest mysticete from the Late Eocene of Peru sheds new light on the origin of baleen whales. Curr. Biol. 27, $1535-1541 \mathrm{e} 2$.

Lambert, O., de Muizon, C., Malinverno, E., Di Celma, C., Urbina, M., Bianucci, G., 2017c. A new odontocete (toothed cetacean) from the Early Miocene of Peru expands the morphological disparity of extinct heterodont dolphins. J. Syst. Palaeontol. 16, 981-1016.

Lambert, O., Bianucci, G., Salas-Gismondi, R., Di Celma, C., Steurbaut, E., Urbina, M., de Muizon, C., 2019. An amphibious whale from the Middle Eocene of Peru reveals early South Pacific dispersal of quadrupedal cetaceans. Curr. Biol. 29, 1352-1359.

Landini, W., Collareta, A., Pesci, F., Di Celma, C., Urbina, M., Bianucci, G., 2017b. A secondary nursery area for the copper shark Carcharhinus brachyurus from the late Miocene of Peru. J. South Am. Earth Sci. 78, 164-174.

Landini, W., Altamirano-Sierra, A., Collareta, A., Di Celma, C., Urbina, M., Bianucci, G., 2017. The late Miocene elasmobranch assemblage from Cerro Colorado (Pisco formation, Peru). J. South Am. Earth Sci. 73, 168-190.

Landini, W., Collareta, A., Di Celma, C., Malinverno, E., Urbina, M., Bianucci, G., 2019. The early Miocene elasmobranch assemblage from Zamaca (chilcatay formation, Peru). J. South Am. Earth Sci. 91, 352-371.

Lemoine, P., Douvillé, R., 1904. Sur le genre Lepidocyclina Gümbel. Mémoire de la Société géologique de France. Paleontologie 32, 1-44.

León, W., Aleman, A., Torres, V., Rosell, W., De La Cruz, O., 2008. Estratigrafía, sedimentología y evolución tectónica de la Cuenca Pisco Oriental. Boletin INGEMMET (Serie D) 27, 1-144.

Lisson, C.I., 1921. Contribución al estudio de algunos foraminferos terciarios provenientes de la región del norte del Peru. Asociación Peruviana Para El Progreso De Las Ciencias, Archivos 1, 1-53. Consulted through Ellis \& Messina Catalogue, accessed February 2019. http://www.micropress.org/em/about.php.

Lisson, C.I., 1925. Algunos fosiles de Paracas. Bol. Soc. Geol. Peru 1, 23-30.

Macharé, J., Ortlieb, L., 1992. Plio-Quaternary vertical motions and the subduction of the Nazca Ridge, central coast of Peru. Tectonophysics 205, 97-108.

Martínez-Cáceres, M., Lambert, O., de Muizon, C., 2017. The anatomy and phylogenetic affinities of Cynthiacetus peruvianus, a large Dorudon-like basilosaurid (Cetacea, Mammalia) from the late Eocene of Peru. Geodiversitas 39, 7-164.

Martini, E., 1971. Standard Tertiary and Quaternary calcareous nannoplankton zonation. Roma. Proc. Second Planktonic Conf. 1970 (2), 739-785.

Marty, R.C., 1989. Stratigraphic and Chemical Sedimentology of Cenozoic Biogenic Sediments from the Pisco and Sechura Basins, Peru. PhD Thesis. Rice University, Houston, Texas.

Marty, R., Dunbar, R., Martin, J.B., Baker, P., 1988. Late Eocene diatomite from the Peruvian coastal desert, coastal upwelling in the eastern Pacific, and Pacific circulation before the terminal Eocene event. Geology 16, 818-822.

Marx, F.G., Collareta, A., Gioncada, A., Post, K., Lambert, O., Bonaccorsi, E., Urbina, M., Bianucci, G., 2017a. How whales used to filter: exceptionally preserved baleen in a Miocene cetotheriid. J. Anat. 231, 212-220.

Marx, F.G., Lambert, O., de Muizon, C., 2017b. A New Miocene Baleen Whale from Peru Deciphers the Dawn of Cetotheriids. vol. 4 Royal Society Open Science article \#170560.

Matteucci, R., Schiavinotto, F., 1977. Studio biometrico di Nephrolepidina, Eulepidina e Cycloclypeus in due campioni dell'Oligocene di Monte La Rocca, L'Aquila (Italia centrale). Geol. Rom. 16, 141-171.

Molina, E., Torres-Silva, A.I., Ćorić, S., Briguglio, A., 2016. Integrated biostratigraphy across the Eocene/Oligocene boundary at Noroña, Cuba, and the question of the extinction of orthophragminids. Newslett. Stratigr. 49, 27-40.

Morales, M.C., Chacaltana, C., Valdiva, W., 2010. Lepidocyclina (Lepidocyclina) peruviana (Cushman) en la Cuenca Pisco: geocronologia y paleoambiente. Sociedad Geológica del Perú, Spec. Publ. 9, 237-240.

Morales, M.C., Tejada-Medina, L., Chacaltana, C., 2013. Significado de la presencia del foraminifero Amphistegina sp. Del Paleógeno en la Cuenca Pisco. I Simposio Internacional de Paleontologia del Perù 1, 29-32.

Muizon, C., Bianucci, G., Martínez-Cáceres, M., Lambert, O., 2019. Mystacodon selenensis, the earliest known toothed mysticete (Cetacea, Mammalia) from the late Eocene of Peru: anatomy, phylogeny, and feeding adaptations. Geodiversitas 41, 401-499.

Mukasa, S.B., Henry, D.J., 1990. The San Nicolas batholith of coastal Peru: early Palaeozoic continental arc or continental rift magmatism? J. Geol. Soc. 147, 27-39.

Murray, J.W., 2006. Ecology and Applications of Benthic Foraminifera. Cambridge University Press, Cambridge.

Nielsen, J.K., Funder, S., 2003. Taphonomy of Eemian marine mollusks and acorn barnacles from eastern Arkhangelsk region, northern Russia. Palaeogeogr. Palaeoclimatol. Palaeoecol. 191, 139-168.

Nomura, S., Maeda, H., 2008. Significance of autochtonous fossil barnacles from the Miocene Natori Group at the Moniwa-Goishi area, northeast Japan. Paleontol. Res. $12,63-79$.

Olsson, A.A., 1928. Contributions to the tertiary paleontology of northern Peru: Part 4, the Peruvian Oligocene. Bull. Am. Paleontol. 17, 99-264.

Olsson, A.A., 1930. Contributions to the tertiary paleontology of northern Peru. Part 3, Eocene Mollusca. Bull. Am. Paleontol. 17, 1-164.

Özcan, E., Less, G., Báldi-Beke, M., Kollányi, K., Acar, F., 2009. Oligo-Miocene foraminiferal record (Miogypsinidae, Lepidocyclinidae and Nummulitidae) from the Western Taurides (SW Turkey): biometry and implications for the regional geology. J. Asian Earth Sci. 34, 740-760.

Özcan, E., Mitchell, S.F., Less, G., Robinson, E., Bryan, J.R., Pignatti, J., Yücel, A.O., 2019. A revised suprageneric classification of American orthophragminids with emphasis on late Paleocene representatives from Jamaica and Alabama. J. Syst. Palaeontol. 0, $1-29$.

Perch-Nielsen, K., 1985. Cenozoic calcareous nannofossils. In: Bolli, H.M., Saunders, J.B., Perch-Nielsen, K. (Eds.), Plankton Stratigraphy. Cambridge University Press, Cambridge, pp. 427-554.

Reijmer, J.J.G., Bauch, T., Schäfer, P., 2012. Carbonate facies patterns in surface sediments of upwelling and non-upwelling shelf environments (Panama, East Pacific). Sedimentology 59, 32-56.

Riedel, W.R., Sanfilippo, A., 1978. Stratigraphy and evolution of tropical Cenozoic radiolarians. Micropaleontology 24, 61-96.

Rivera, R., 1957. Moluscos fosiles de la formacion Paracas, dpto. de Ica. Bol. Soc. Geol. Peru 32, 165-219.

Robertson, A.H.F., Eaton, S., Follows, E.J., McCallum, J.E., 1991. The role of local tectonics versus global sea-level change in the Neogene evolution of Cyprus margin. Special Publ. Int. Assoc. Sedimentol. 12, 331-339.

Robinson, E., 1996. Using larger foraminifera in high resolution biostratigraphy: an example from the Eocene of the Gulf of Mexico and Northern Caribbean. Palaios 11, 220-229.

Robinson, E., 1997. The Eocene larger foraminifer Lepidocyclina ariana Cole and Ponton from the so-called Polylepidina gardnerae horizon at little stave creek, Alabama. J. Paleontol. 71, 1-5.

Robinson, E., 2004. Zoning the White Limestone Group of Jamaica using larger foraminiferal genera: a review and proposal. Cainozoic Res. 3, 39-75.

Rutten, L., 1928. On Tertiary rocks and foraminifera from north-western Peru. Proc. Sec. Sci. Koninklijke Akademie van Wetenschappen te Amsterdam 31, 931-948.

Rutten, M.G., 1935. Larger foraminifera of northern santa clara province, Cuba. J. Paleontol. 9, 527-545.

Scheffen, W., 1932. Ostindische Lepidocyclinen 1. Wetenschappelijke mededeeelingen. Dienst van de Mijnbouw in Nederlandsch Oost-Indie 21, 5-76.

Schiavinotto, F., 1979. Miogypsina e Lepidocyclina del Monte La Serra (L'Aquila-Appennino Centrale). Geol. Rom. 18, 253-293.

Schiavinotto, F., 1992. The neanic stage of Nephrolepidina tourneri: biometry and biostratigraphic implications. Boll. Soc. Paleontol. Ital. 31, 189-206.

Schiavinotto, F., 1995. Environmental influence on the neanic acceleration in OligoMiocene Nephrolepidina. Geol. Rom. 31, 273-283.

Schiavinotto, F., 2010. Neanic stage biometry in Nephrolepidina from the upper Oligocene of lonedo (lugo di Vicenza - northern Italy). Boll. Soc. Paleontol. Ital. 49, 173-194.

Serra-Kiel, J., Ferràndez-Cañadell, C., García-Senz, J., Huerta, P.P.H., 2007. Cainozoic larger foraminifera from Dominican Republic. Bol. Geol. Min. 118, 359-384.

Tan, Sin Hok, 1932. On the genus Cycloclypeus carpenter. Part I, and an appendix on the heterostegines of tjimanggoe, S. Bantam, java. Wetenschappelijke Mededeelingen Dienst van den Mijnbouw in Nederlandsch-Indië 19, 3-194.

Tan, Sin Hok, 1935. Die peri-embryonalen Aquatorialkammern bei einigen Orbitoididen. De Ingenieur in Nederlandsch-Indie, IV. Geol. Mijnb. 2, 113-126.

Todd, J.U., 1933. Metagenesis in Lepidocyclina from the Eocene of Peru. Geol. Mag. 70, 393-396.

Todd, J.U., Barker, R.W., 1932. Tertiary orbitoids from north-western Peru. Geol. Mag. $69,528-543$.

Torres-Silva, A.I., Hohenegger, J., Ćorić, S., Briguglio, A., 2017. Biostratigraphy and evolutionary tendencies of Eocene heterostegines in Western and Central Cuba based on morphometric analyses. Palaios 32, 44-60.

Tsuchi, R., Shuto, T., Takayama, T., Fujiyoshi, A., Koizumi, I., Ibaraki, M., Rangel, Z.C., Aldana, A.M., 1988. Fundamental data on Cenozoic biostratigra-phy of the Pacific coast of Peru. In: Tsuchi, R. (Ed.), Reports of Andean Studies, Special Volume 2. Shizuoka University, pp. 45-70.

Uhen, M.D., Pyenson, N.D., DeVries, T.J., Urbina, M., Renne, P.R., 2011. New middle Eocene whales from the Pisco Basin of Peru. J. Paleontol. 85, 955-969.

van de Geyn, A.E., Van der Vlerk, I.M., 1935. A monograph on the Orbitoididae, occurring in the Tertiary of America. Leidse Geol. Meded. 7, 221-272.

van der Vlerk, I.M., 1923. Een nieuwe Cycloclypeus van Oost-borneo. Sammlungen des geologischen Reichsmuseum, Series 1, 137-140 10.

van der Vlerk, I.M., 1959. Modifications de l'ontogénèse pendant l'évolution des Lépidocyclines (Foraminifères). Bulletin de la Société Géologique de France, Notes et Mémoires, Série 7 (1), 669-673.

van der Vlerk, I.M., 1963. Biometric research on Lepidocyclina. Micropaleontology 9, 425-426.

van Vessem, E.J., 1978. Study of Lepidocyclinidae from south-east Asia, particularly from java and borneo. Utrecht Micropalaeontol. Bull. 19, 1-163.

Vaughan, T.W., 1924. American and European Tertiary larger foraminifera. Bull. Geol. Soc. Am. 35, 785-822.

Vaughan, T.W., Cole, W.S., 1941. Preliminary report on the Cretaceous and Tertiary foraminifera of Trinidad, British west indies. Geol. Soc. Am. Spec. Pap. 30, 1-131.

Wade, B.S., Pearson, P.N., Berggren, W.A., Pälike, H., 2011. Review and revision of Cenozoic tropical planktonic foraminiferal biostratigraphy and calibration to the geomagnetic polarity and astronomical time scale. Earth Sci. Rev. 104, 111-142.

Young, J.R., Bown, P.R., Lees, J.A., 2019. Nannotax3 website. International nannoplankton association. Accessed September 2019. http://www.mikrotax.org/ Nannotax3. 